ALINE INOCENTI

A experiência da reconstrução mamária para mulheres com câncer de mama 


\section{ALINE INOCENTI}

\section{A experiência da reconstrução mamária para mulheres com câncer de mama}

Dissertação apresentada à Escola de Enfermagem de Ribeirão Preto da Universidade de São Paulo para obtenção do título de Mestre junto ao Programa de PósGraduação Enfermagem em Saúde Pública

Área de Concentração: Enfermagem em Saúde Pública. Inserida na linha de pesquisa: Assistência à saúde da mulher no ciclo vital

Orientadora: Profa. Dra.

Marislei Sanches Panobianco

Ribeirão Preto

2012 
AUTORIZO A REPRODUÇÃO E DIVULGAÇÃO TOTAL E PARCIAL DESTE TRABALHO, POR QUALQUER MEIO CONVENCIONAL OU ELETRÔNICO, PARA FINS DE ESTUDO E PESQUISA, DESDE QUE CITADA A FONTE.

FICHA CATALOGRÁFICA

Inocenti, Aline

A experiência da reconstrução mamária para mulheres com câncer de mama. Ribeirão Preto, 2012.

84p.; $30 \mathrm{~cm}$.

Dissertação de Mestrado, apresentada à Escola de Enfermagem de Ribeirão Preto/USP - Área de concentração: Enfermagem em Saúde Pública

Orientadora: Panobianco, Marislei Sanches

1. Neoplasias da mama. 2. Reabilitação. 3. Saúde da Mulher. 4. Mamoplastia. 


\section{FOLHA DE APROVAÇÃO}

Aline Inocenti

A experiência da reconstrução mamária para mulheres com câncer de mama

Dissertação apresentada à Escola de Enfermagem de Ribeirão Preto da Universidade de São Paulo para obtenção do título de Mestre junto ao Programa de PósGraduação Enfermagem em Saúde Pública

Área de Concentração: Enfermagem em Saúde Pública.

Aprovado em:

Banca Examinadora

Prof. Dr.

Instituição:

Assinatura:

Prof. Dr.

Instituição:

Assinatura:

Prof. Dr.

Instituição:

Assinatura: 


\section{Dedicatória}

A meus pais, Octávio e Neide, meus eternos amores, que nunca mediram esforços para garantirem a minha felicidade.

À minha irmã Adriana e a meu cunhado Radamés, que sempre me acolheram, incentivaram e estiveram ao meu lado nesta caminhada.

Ao meu querido sobrinho Guilherme, minha razão de alegria e orgulho.

Ao Francisco, por me incentivar sempre a buscar o meu melhor e pelo amor, respeito e carinho que tem por mim. 


\section{Agradecimento Especial}

A Deus, pelo dom da vida e por capacitar-me para conseguir finalizar mais esta etapa do meu crescimento profissional.

Às mulheres do Rema, pelo constante exemplo de força e pelo imenso carinho com que me receberam no grupo e, em especial, às mulheres que fizeram parte deste estudo, pela generosidade em compartilhar suas histórias pessoais. 


\section{Agradecimentos}

À Profa. Dra. Marislei Sanches Panobianco, pela generosidade e carinho com que me conduziu durante todo este trabalho, pelos ricos ensinamentos e por oferecer desafios que possibilitaram meu crescimento pessoal e profissional.

À Profa. Dra. Inês Gimenes Rodrigues, por possibilitar o meu despertar para a pesquisa e por sempre estar disposta a escutar-me com sinceridade e delicadeza.

À Profa. Dra. Thais de Oliveira Gozzo, pela amizade e por suas contribuições para o enriquecimento desta pesquisa.

Às professoras Ana Maria de Almeida e Maria Helena Larcher Caliri, pela preciosa contribuição no exame de qualificação, por meio de sugestões que contribuíram sobremaneira para o aprimoramento deste trabalho.

À Maria Antonieta Spinoso Prado, por me ouvir, aconselhar e pela valiosa amizade.

Às amigas e companheiras da pós-graduação, Simone, Patrícia, Edilaine, Talita, Marceila, e todas as que, mesmo não citadas, compartilharam comigo momentos de alegria, descontração, preocupações e angústias.

Aos amigos da vida toda, Élina, Juliana, Daniel, Karen e Mileni, por me confortarem quando precisei e por se alegrarem comigo nas minhas conquistas.

A todos os profissionais do REMA, pela amizade e companheirismo.

Aos funcionários da EERP-USP, em especial à Shirley, pelo apoio durante o desenvolvimento deste trabalho.

À CAPES, pelo apoio financeiro por meio da concessão da bolsa de estudos.

A todos que, mesmo não tendo sido citados, fazem parte da minha vida e estão em meu coração. 
"Enquanto estiver vivo, sinta-se vivo. Se sentir saudades do que fazia, volte a fazê-lo. $\mathcal{N} a ̃ o$ viva de fotografias amareladas... Continue, quando todos esperam que desistas. $\mathcal{N} a \tilde{o}$ deixe que enferruje o ferro que existe em você. Faça com que em vez de pena, tenham respeito por você. Quando não conseguir correr através dos anos, trote. Quando não conseguir trotar, caminhe. Quando não conseguir caminhar, use uma bengala. Mas nunca se detenha." 


\section{RESUMO}

INOCENTI, A. A experiência da reconstrução mamária para mulheres com câncer de mama. 2012. 84p. Dissertação (Mestrado) - Escola de Enfermagem de Ribeirão Preto, Universidade de São Paulo, Ribeirão Preto, 2012.

Este estudo descritivo, com abordagem qualitativa, teve como objetivo compreender como é a experiência da reconstrução mamária na vida de mulheres com câncer de mama. Para obtenção dos dados, foram realizadas entrevistas semiestruturadas com 14 mulheres submetidas à cirurgia para reconstrução mamária e cadastradas em um serviço especializado em reabilitação pós-mastectomia. Para tratamento dos dados, utilizou-se o método de análise temática proposto por Bardin, o qual proporcionou a obtenção de dois temas principais: o primeiro abordou a experiência das mulheres entre o diagnóstico e a realização da cirurgia reconstrutora e agrupou categorias referentes aos sentimentos e às atitudes das mulheres diante do diagnóstico de câncer de mama e como se deu o processo decisório pela reconstrução mamária. No segundo, as categorias estiveram relacionadas à forma como a mulher se vê, depois da reconstrução, e o que a mesma significou em sua vida, como ela percebe seus benefícios e convive com as limitações decorrentes da cirurgia reconstrutora, bem como o papel das diversas redes de apoio em sua trajetória. Neste estudo, dentre outros motivos apontados pelas mulheres na escolha da reconstrução, destacou-se a influência do médico na decisão pela cirurgia. A recuperação da mama devolveu a algumas mulheres sua autoestima e a sensação de estarem completas novamente, ajudou-as a recuperar sua autoimagem e a superar o trauma causado pela doença, proporcionando-lhes, por exemplo, a segurança para manterem ou iniciarem um relacionamento afetivo e sexual com um parceiro. As complicações no pós-operatório desencorajaram as mulheres a finalizarem a cirurgia e provocaram o medo de uma nova perda, as cicatrizes e deformidades na mama causaram insatisfação e a perda da sensibilidade do retalho ocasionou, em alguns casos, comprometimentos na esfera sexual e na percepção da neomama. Observou-se que as redes de apoio às mulheres com câncer se mostraram presentes em todas as fases do adoecer, desde o diagnóstico até a reabilitação. A família, os amigos e o grupo de reabilitação foram as fontes de suporte mais frequentes, e a participação deles mostrou-se fundamental para a reinserção das mulheres na sociedade. Os dados obtidos neste estudo podem oferecer subsídios para a implementação de ações no âmbito do atendimento às mulheres com câncer de mama, as quais devem envolver paciente, família e profissionais de saúde.

Palavras-chave: Neoplasias da mama, Reabilitação, Saúde da Mulher, Mamoplastia. 


\begin{abstract}
INOCENTI, A. The experience of breast reconstruction for women with breast cancer. 2012. 84p. Dissertation (Master) - School of Nursing of Ribeirão Preto, University of São Paulo, Ribeirão Preto, 2012.

This descriptive and qualitative study aimed at understanding how is the experience of breast reconstruction in the lives of women with breast cancer. To obtain data, semi-structured interviews with 14 women undergoing surgery for breast reconstruction enrolled in a specialized rehabilitation service post-mastectomy were performed. Data processing was organized using the methodology of thematic analysis proposed by Bardin, which provided the achievement of two main themes: the first showed the experience of women during the period between diagnosis and reconstructive surgery and grouped categories related to feelings and attitudes of women after the diagnosis of breast cancer and how was the decisionmaking process for breast reconstruction. In the second, the categories were related to how the woman sees herself after reconstruction and what it meant in her life, how she realizes its benefits, how she lives with the limitations resulting from reconstructive surgery as well the role of the various support networks in her trajectory. In this study, among other reasons reported by women to choose the reconstruction, it is highlighted the influence of the physician in deciding on doing the surgery. The recovery of the breast helped to build the selfesteem to some women and restore the sense of being whole again; helped them regain their self-image and overcome the trauma caused by the disease which provided, for example, the security to maintain or initiate an affective and sexual relationship with a partner. The postoperative complications discouraged women from doing surgery and caused fear of a new loss; the scars and breast deformities caused dissatisfaction, and the loss of sensation of the areola and nipple caused, in some cases, problems in the sexual sphere and breast awareness. It was observed that the support networks for women with breast cancer assisted them in all stages of illness, from diagnosis to rehabilitation. Family, friends and the rehabilitation group were the most frequent sources of support and their participation proved vital for the reintegration of women in society. The data obtained in this study may provide support for the implementation of actions related to the care of women with breast cancer, which should involve patient, family and health professionals.
\end{abstract}

Key-words: Breast neoplasms, Rehabilitation, Women's health, Mammaplasty. 


\section{RESUMEN}

INOCENTI, A. La experiencia de reconstrucción mamaria para mujeres con cáncer de mama. 2012. 84p. Disertación (Maestría) - Escuela de Enfermería de Ribeirão Preto. Universidad de São Paulo, Ribeirão Preto, 2012.

Este estudio descriptivo y cualitativo objetivó comprender cómo es la experiencia de reconstrucción mamaria en las vidas de mujeres con cáncer de mama. Para obtener los datos, fueron realizadas entrevistas semi-estructuradas con 14 mujeres sometidas a cirugía para la reconstrucción mamaria registradas en un servicio especializado en rehabilitación postmastectomía. Para el procesamiento de datos, se utilizó el método de análisis temático de Bardin, el cual proporcionó la obtención de dos temas principales: el primer trata de la experiencia de las mujeres en el periodo entre el diagnóstico y la cirugía reconstructiva y agrupó categorías referentes a los sentimientos y actitudes de las mujeres delante del diagnóstico de cáncer de mama y cómo fue el proceso decisorio en relación a la reconstrucción mamaria. En el segundo, las categorías estaban relacionadas a la forma cómo la mujer se ve a sí misma después de la reconstrucción y lo que eso significó en su vida; cómo ella percebe sus beneficios, cómo convive con las limitaciones derivadas de la cirugía reconstructiva bien cómo el papel de las distintas redes de apoyo en su trayectoria. En este estudio, entre otras razones citadas por las mujeres para la elección de la reconstrucción, se destacó la influencia del médico en la decisión acerca de la cirugía. La recuperación de la mama volvió a algunas mujeres la autoestima y la sensación de que están completas nuevamente, les ayudó a recuperar su autoimagen y superar el trauma causado por la enfermedad, proporcionándoles, por ejemplo, la seguridad para mantener o iniciar una relación afectiva y sexual con una pareja. Las complicaciones postoperatorias desanimaran a las mujeres para finalizar la cirugía y causaron el temor de una nueva pérdida; las cicatrices y deformidades en la mama causaron insatisfacción; y la pérdida de la sensibilidad del pezón causó, en algunos casos, comprometimientos en la esfera sexual y en la percepción de la mama. Se observó que las redes de apoyo para las mujeres con cáncer de mama mostraron estar presentes en todas las etapas de la enfermedad, desde el diagnóstico hasta la rehabilitación. Familia, amigos y el grupo de rehabilitación fueron las fuentes de apoyo más frecuentes y su participación fue vital para la re-integración de las mujeres en la sociedad. Los datos obtenidos en este estudio pueden ofrecer subsidios para la implementación de las acciones en el ámbito del cuidado de las mujeres con cáncer de mama, los cuales deben envolver al paciente, familia y profesionales de la salud.

Palabras clave: Neoplasias de la mama, Rehabilitación, Salud de la mujer, Mamoplastia. 


\section{SUMÁRIO}

RESUMO

ABSTRACT

RESUMEN

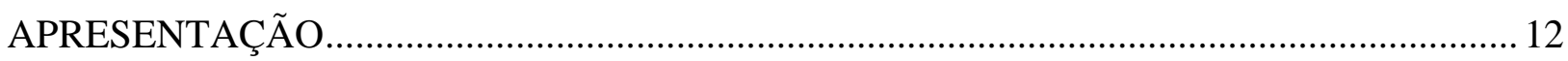

1. INTRODUÇÃ

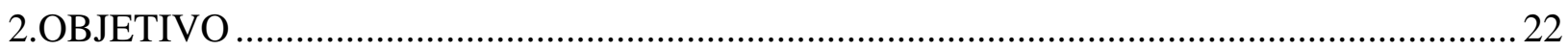

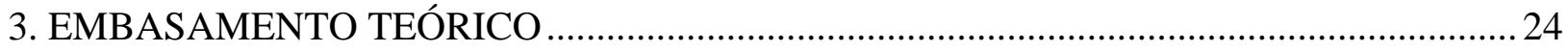

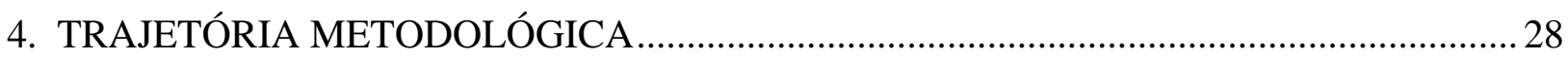

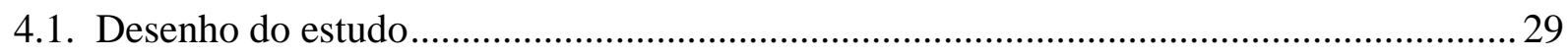

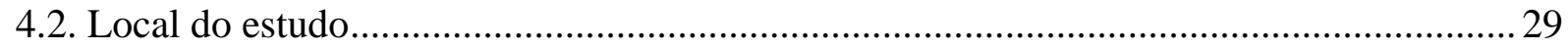

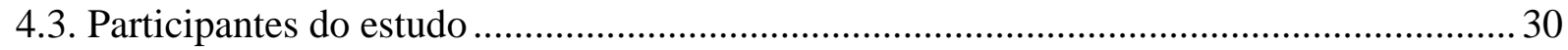

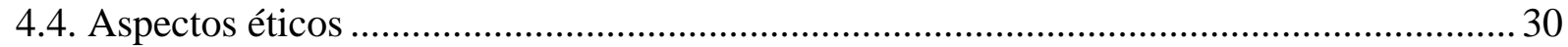

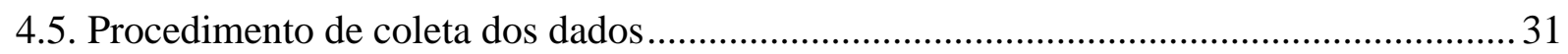

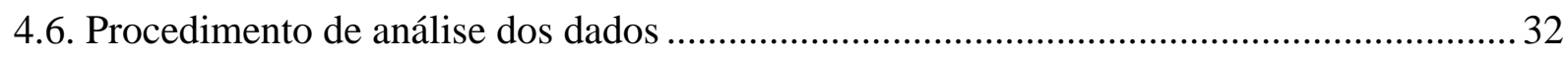

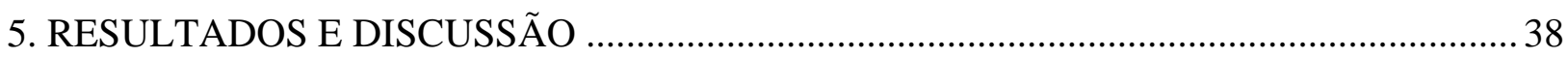

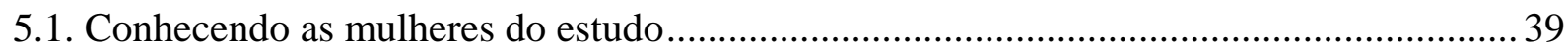

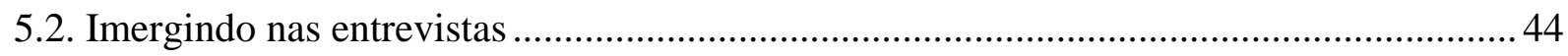

5.2.1. Do diagnóstico à decisão pela reconstrução mamária .............................................. 44

5.2.2. A experiência pós-reconstrução mamária ................................................................ 51

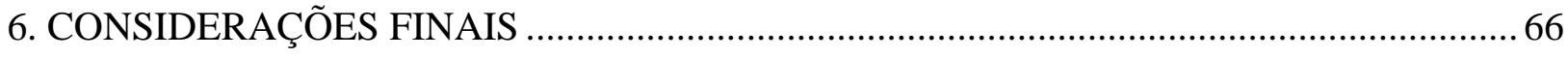

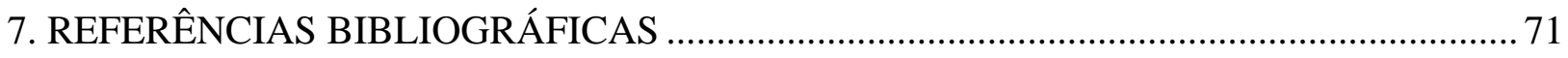

APÊNDICES

ANEXO 


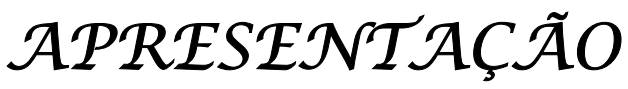


Durante o curso de graduação em enfermagem, o Hospital do Câncer de Londrina constituiu um campo de estágio de grande importância em minha formação, não somente por proporcionar oportunidade de atendimento a pacientes com os mais diversos tipos de neoplasias, como também por permitir uma aproximação com a realidade destes, desde o diagnóstico, sessões de radioterapia e quimioterapia, até a observação de cirurgias oncológicas, como a mastectomia. A partir de então, interessei-me pela área de oncologia e por aperfeiçoar-me profissionalmente nessa área.

Sabendo do meu interesse pelo assunto, uma professora da graduação convidou-me a integrar um projeto de extensão universitária, no qual realizávamos reuniões semanais para a discussão de técnicas de comunicação terapêutica na abordagem ao paciente oncológico, além de visitas domiciliares com a finalidade de aprimorarmos a comunicação com essa clientela. Despertou-me a atenção a história de uma paciente de 22 anos que, ao descobrir-se com câncer de mama iniciou, uma batalha em busca da cura, passando por vários procedimentos, inclusive a mastectomia. Ela não tinha condições físicas de ser submetida a uma cirurgia de reconstrução mamária e relatava que a ausência da mama era a maior causa de seu sofrimento.

Ainda na graduação participei de estágio curricular no Serviço de Internação Domiciliar de Londrina, onde posteriormente desenvolvi meu Trabalho de Conclusão de Curso com os familiares cuidadores de pacientes oncológicos atendidos pela equipe de Cuidados Paliativos do referido serviço, a fim de conhecer os sentimentos destes durante sua relação de cuidado com o familiar doente.

Após concluir a graduação, durante visitas à Escola de Enfermagem de Ribeirão Preto - USP, conheci o Núcleo de Ensino, Pesquisa e Assistência na Reabilitação de Mastectomizadas-REMA. A proposta desse serviço, de atendimento integral às mulheres acometidas pelo câncer de mama, despertou meu interesse e hoje integro a equipe do núcleo, como voluntária. Conviver com essas mulheres instigou-me a continuar estudando a temática do câncer de mama, e esta investigação tem a proposta de compreender a experiência da reconstrução mamária na vida de mulheres com câncer de mama.

Acredito que ela possa contribuir para o aprimoramento da assistência à saúde dessas mulheres, assim como difundir o conhecimento para outros segmentos da área da saúde e trazer subsídios para futuras produções científicas. 
O câncer de mama é o segundo tipo de câncer mais frequente no mundo e o mais comum entre as mulheres, constituindo a maior causa de óbitos por câncer na população feminina brasileira (BRASIL, 2009).

A prevenção primária dessa neoplasia ainda não é completamente possível, devido à variação dos fatores de risco e à influência de características genéticas em sua etiologia. No entanto, estratégias de rastreamento podem ser usadas na detecção precoce do tumor. O exame clínico, a ultrassonografia e a mamografia são procedimentos que tornam possível a detecção do tumor na sua fase inicial (CORBELLINI, 2001; MOLINA; DALBEN; DE LUCA, 2003).

Trata-se de um tipo de câncer de bom prognóstico quando diagnosticado e tratado precocemente. Porém, o atraso no diagnóstico tem impedido que as pacientes sejam beneficiadas pelos procedimentos terapêuticos que poderiam reverter o curso clínico da doença (WHO, 2002).

Estudo realizado, no Instituto Nacional de Câncer -INCA, que teve como objetivo avaliar os fatores que levam ao retardo na confirmação diagnóstica de lesões mamárias suspeitas de câncer, concluiu que os altos índices de casos de câncer de mama avançados estão relacionados à ausência, no país, de um programa estruturado para a detecção precoce dessa neoplasia (RESENDE et al., 2009).

Desde 2004, o Ministério da Saúde recomenda para mulheres assintomáticas, na faixa etária entre 50 e 69 anos, a realização de mamografia de rastreamento com intervalos nunca superiores a dois anos. Para mulheres entre 40 e 49 anos de idade, recomendava-se o rastreamento anual por meio do exame clínico da mama. Porém, a partir de 29 de abril de 2009, quando entrou em vigor a Lei 11.664, de 29 de abril de 2008, que assegura a realização de exame mamográfico a todas as mulheres a partir dos 40 anos de idade pelo Sistema Único de Saúde (SUS), essa realidade vem se modificando, ainda que a passos lentos (BRASIL, 2009).

Considerando-se o estágio avançado em que a doença é descoberta, aumentam as dificuldades para o tratamento, são menores as chances de sobrevida das pacientes e há um comprometimento nos resultados da terapêutica, por isso o número de mastectomias realizadas no Brasil ainda é alto (MAKLUF; DIAS; BARRA, 2006; BRASIL, 2004).

Como modalidades de tratamento podem ser utilizadas quatro terapias, em associação ou isoladamente: cirurgia, radioterapia, quimioterapia e terapia com agentes biológicos como hormônio, anticorpos ou fatores de crescimento (ANJOS; ZAGO, 2006). 
A cirurgia, no entanto, desde o final do século XIX tem sido o tratamento tradicional do câncer de mama (FREITAS JUNIOR et al., 2001). O estadiamento clínico e o tipo histológico são fatores considerados na indicação de diferentes tipos de cirurgia, podendo ser conservadoras, por meio da ressecção de um segmento da mama (setorectomia, tumorectomia alargada e quadrantectomia), com retirada dos gânglios axilares ou linfonodo sentinela, ou não conservadora (mastectomia) (BRASIL, 2004).

A mastectomia radical clássica (ou de Halsted) permaneceu como tratamento dessa neoplasia por aproximadamente 60 anos, porém, após algumas alterações, foram introduzidas novas técnicas, com a preservação de um ou ambos os músculos peitorais, sendo elas, respectivamente, mastectomia à Patey e mastectomia à Madden (FREITAS JUNIOR et al., 2001).

A retirada da mama é realizada também como profilaxia em algumas mulheres com risco de câncer de mama por possuírem mutações nos genes BRCA1 ou BRCA2, supressores de tumor, sendo o processo de decisão por tal cirurgia realizado em conjunto com o cirurgião oncologista. Estimativas apontam incidência de câncer de mama em até 80\% das mulheres portadoras de mutações nos referidos genes. A presença de antecedentes familiares com a doença resulta em riscos individuais bem estabelecidos, e sua investigação tem ganhado crescente importância na pesquisa do câncer de mama (DJOHAN; GAGE; BERNARD, 2008; AMENDOLA; VIEIRA, 2005).

A cirurgia, além de danificar a integridade física, pode levar a repercussões emocionais importantes, alterando a imagem psíquica que a mulher tem de si mesma e de sua sexualidade, interferindo nas atividades domésticas e profissionais (ROSSI; SANTOS, 2003; MALUF; MORI; BARROS, 2005; CYRILLO, 2000).

Diante da necessidade da retirada de toda a mama, a mulher passa a conviver com a mutilação de um órgão que simboliza sua feminilidade e a maternidade, acarretando uma série de consequências psicológicas, físicas e sociais relacionadas à imagem corporal (AZEVEDO, 2006). Sendo assim, mulheres mastectomizadas ou com deformidade pós-cirúrgica da mama podem sentir-se inferiorizadas e menos capazes de estabelecer novos vínculos afetivos, se comparadas àquelas que possuem mamas não operadas, e o relacionamento sexual pode tornar-se abalado pela sensação de deformidade e constrangimento (AZEVEDO; LOPES, 2005; HUGUET et al., 2009).

Na tentativa de promover uma maior semelhança à aparência feminina, a maioria das mulheres, após a mastectomia, utiliza prótese mamária externa (JESUS; LOPES, 2003). A prótese é indicada para melhora do aspecto estético e também para ajudar a manter a postura do ombro e da coluna vertebral. No entanto, alguns estudos mostram que essa forma de 
restauração da mama não é incorporada à autoimagem da mulher. É muitas vezes vivenciada como um objeto estranho, que lembra a doença, associado a sentimentos de vulnerabilidade (REABY, 1998; SILVA; SANTOS, 2008).

Uma alternativa para minimizar as consequências desfavoráveis da mastectomia e, muitas vezes, do uso da prótese mamária externa, é a realização das reconstruções mamárias, imediatas ou tardias, que têm como objetivo diminuir o traumatismo psicológico, melhorar o contorno corporal, preservar ou restituir a integridade pessoal, aumentando o otimismo para a cura e melhorando assim a qualidade de vida (SANTOS,1998).

Cada vez mais, a comunidade científica desenvolve novas técnicas com recursos capazes de criar uma mama semelhante em forma e aparência à natural, sendo várias as possibilidades oferecidas pela cirurgia oncológica, nos dias atuais. Cirurgias imediatas, tardias, com ou sem uso de expansor, implantes de silicone e enxertos com tecidos autólogos são realizados com o objetivo de devolver à mulher a mama retirada.

Esse esforço está relacionado à conscientização de que as mamas femininas são ícones de feminilidade e erotização, além de os cirurgiões considerarem que tais procedimentos, na maioria das vezes, não colocam em risco o perfil clínico da mulher (TEIXEIRA, 2008).

Paredes et al. (2006) destacam alguns fatores que devem ser observados antes da decisão pela reconstrução: a obesidade aumenta as complicações por maior probabilidade de necrose e infecções; diabetes, tabagismo e idade avançada são fatores que podem levar ao aumento das complicações, como necrose do retalho, por estarem associados ao comprometimento da microcirculação. Deve-se avaliar, também, a qualidade da pele, dos músculos peitorais e dorsais e da parede abdominal.

A reconstrução imediata é indicada quando existem poucas chances de morbidade no pós-operatório. Como a reconstrução é realizada instantes após a retirada da mama, uma das vantagens desse tipo de cirurgia é a necessidade de apenas uma anestesia para ambos os procedimentos.

No entanto, Chagas et al. (2008) afirmam que as complicações no pós-operatório, como infecção, demora na cicatrização e queda no estado geral da paciente são mais frequentes em reconstruções imediatas e podem levar ao atraso do tratamento adjuvante do câncer de mama.

As cirurgias tardias geralmente são realizadas em mulheres com a doença em estádios avançados (III e IV), ou que terminaram o tratamento adjuvante sem apresentar sinais de recorrência local ou a distância. A radioterapia é considerada um fator importante no 
adiamento da reconstrução mamária pós-mastectomia por dificultar a expansão tecidual nos locais irradiados (GREGÓRIO; SBALCHIERO; LEAL, 2007; PETER; CORDEIRO, 2008).

Esse tipo de cirurgia costuma ter longa duração e envolver diversas etapas, podendo haver a necessidade de três a quatro intervenções para a obtenção do resultado final, o que pode levar meses ou anos. Essa demora, aliada ao desgaste psicológico vivenciado pela mulher durante o tratamento e à ansiedade em relação à possibilidade de ter a autoestima restabelecida, pode gerar sentimentos de decepção ao enxergar-se com a mama incompleta no decorrer do processo de reconstrução.

Outra opção é a chamada reconstrução “tardia - imediata” que envolve a implantação de um expansor de pele durante a mastectomia e a espera de exames patológicos para predizer a necessidade ou não da radioterapia; não sendo necessária, a paciente poderá submeter-se à reconstrução imediatamente, caso contrário, esta poderá ser realizada após o término do tratamento radioterápico, tendo sido a pele preservada com o uso do expansor, a fim de se obter melhores resultados estéticos (DJOHAN; GAGE; BERNARD, 2008).

Geralmente, as cirurgias reconstrutoras da mama consistem de dois estágios: restauração do montículo mamário e reconstrução do complexo aréolo-mamilar. Em alguns casos, é também necessária intervenção cirúrgica para simetrização das mamas.

Quando há a possibilidade de preservação da pele da mama durante a mastectomia, pode-se implantar uma prótese definitiva abaixo do músculo peitoral, coberta pela pele. Caso não haja cobertura de pele suficiente, há a opção do implante de um expansor mamário, até que haja volume de pele suficiente para a instalação da prótese. As vantagens desse tipo de reconstrução incluem um tempo relativamente curto de anestesia e procedimento (uma a duas horas), menor taxa de morbidade, ajuste do volume e ausência de cicatrizes em outras áreas do corpo. Algumas desvantagens são o prolongado tempo para alcançar um montículo mamário e várias visitas ao cirurgião plástico para a inflação do expansor. Ocasionalmente podem surgir complicações como infecções, extrusão pós-radioterapia, necrose da pele e contratura capsular (GUIMARÃES; DAHER; CAMAROTA, 2008; ALMEIDA JUNIOR, 2009; PETER; CORDEIRO, 2008).

As reconstruções autólogas mais frequentes são as que utilizam músculos e tecidos das regiões abdominal e dorsal, respectivamente as cirurgias com retalho transverso do músculo reto do abdômen (TRAM) e retalho obtido a partir do músculo grande dorsal. Isso se deve ao fato de as mesmas apresentarem resultado estético semelhante ao da mama natural.

O uso do retalho TRAM é indicado para mulheres cuja idade não ultrapasse os 65 anos, que não necessitem manter a integridade de sua parede abdominal, com vistas a uma 
futura gravidez ou prática de esportes de alta competição, não sejam fumantes e tenham uma atitude positiva frente à intervenção e que apresentem grande volume mamário e área doadora abdominal com volume suficiente. Algumas vantagens dessa técnica são a naturalidade e a simetria da mama obtida, a realização de uma abdominoplastia e a não necessidade do uso de prótese de silicone, o que possibilita a realização de radioterapia adjuvante. Hematomas, seromas, flacidez e hérnia abdominal e necrose do retalho são alguns problemas que podem surgir (DONCATTO; ASCOLI; DIAS, 2007; LOMBARDI et al., 2002; LOZANO; ROLDÁN; ESCUDERO, 2005).

Outra consequência comum da reconstrução mamária com retalho TRAM é a perda da sensibilidade tátil da nova mama. As pacientes que se submetem a este tipo de cirurgia relatam sentirem-se insatisfeitas em relação às cicatrizes abdominais e principalmente à perda da sensibilidade (SÁNCHEZ et al., 2006). Algumas mudanças têm ocorrido nas técnicas cirúrgicas com retalhos TRAM, por meio da utilização da microcirurgia para anastomose de nervos sensoriais.

Estudo mostrou que a maioria das mulheres percebeu uma melhora progressiva da sensibilidade tátil do retalho e aceitou a neomama como se fosse verdadeiramente sua, apesar de considerá-la diferente da outra mama (GOMES, 2004).

Isso se justifica pelo fato de o retorno sensitivo contribuir para a aceitação subjetiva da nova mama pela mulher, auxiliando nas esferas emocional e sexual, além de evitar danos como escoriações e queimaduras na mama, entre outros, devido à falta de sensibilidade.

Outro tipo de cirurgia é a que utiliza o retalho obtido a partir do músculo grande dorsal, que é transferido e posicionado no tórax da paciente por rotação, a partir da volta da mama. Nesse caso há menor morbidade da área doadora e melhor irrigação, o que permite que existam menores complicações como necrose do retalho. A grande desvantagem é a pequena projeção, o que geralmente exige a utilização concomitante de prótese para obtenção de maior volume. É indicado para reconstrução de mamas pequenas, e algumas complicações e limitações como hematomas, seromas e necrose do retalho podem ocorrer neste tipo de cirurgia (PETER; CORDEIRO, 2008; PAREDES et al. 2006).

Em média, dois a três meses após a reconstrução completa do montículo mamário, quando a mama está estabilizada, é realizada a reconstrução do complexo aréolo-mamilar. Este pode ser obtido por meio de enxerto de outras partes do corpo. Outras opções são a tatuagem intradérmica para obtenção da aréola e enxerto obtido do mamilo contralateral para a formação do novo mamilo. Incompatibilidade de cor, mau posicionamento, tamanho incorreto e necrose podem ocorrer nesse tipo de cirurgia (ROLDÁN; LOZANO; OROZ, 2005). 
Não existe um método considerado ideal. Cada paciente, em parceria com seu cirurgião, pode discutir qual o tipo de reconstrução adequado, levando em consideração o quadro clínico, estágio da doença, opções viáveis de cirurgia e necessidade ou não de terapia adjuvante.

As reconstruções autólogas, bem como as que utilizam expansores de pele e implantes de silicone, têm como objetivo a criação de uma mama simétrica e natural e oferecem, assim, benefícios físicos e psicológicos (DONCATTO; ASCOLI; DIAS, 2007).

Nesse sentido, alguns estudos mostram que a reconstrução também colabora para a identificação sexual da mulher, sua autoimagem e autoestima (CARVALHO; CORREA, 1998; VIANNA, 2004).

No Brasil, a repercussão desses aspectos levou à criação da Lei 9.797 de 06 de maio de 1999 que prevê que toda mulher submetida à mastectomia por câncer de mama tem direito à cirurgia plástica reparadora da mama pela rede de saúde do Sistema Único de Saúde - SUS (BRASIL, 1999).

Apesar de a cirurgia reconstrutora ser oferecida gratuitamente pelo SUS, muitas mulheres optam por não realizá-la. Nesse contexto, estudo de Braganholo (2007) com mulheres mastectomizadas que não realizaram a reconstrução mamária mostrou que muitas delas temem pelo sofrimento com uma nova cirurgia e com as complicações que podem advir do pós-operatório.

Os ginecologistas, cirurgiões gerais, oncologistas e radiologistas foram durante muitos anos, contra qualquer tratamento reconstrutor, afirmando que a aplicação de tecido sobre a região peitoral dificultava ou impedia maior exploração para detectar qualquer sinal de recidiva local da doença (SOUZA, 2007; PETER; CORDEIRO, 2008).

Nos dias atuais, a opinião dos médicos tem se mostrado favorável à reconstrução mamária e já se sabe que tal procedimento não influencia na detecção de recidiva local. De acordo com dados do Instituto Nacional de Câncer (BRASIL, 2009), o Hospital do Câncer III, unidade do INCA especializada no tratamento do câncer de mama, realizou em 2008, 287 cirurgias plásticas para reconstrução mamária, mostrando 300\% de aumento em relação ao ano de 2003, no qual foram realizadas 94 reconstruções.

Muitas são as razões pelas quais as mulheres realizam a cirurgia reconstrutora, mas a busca por restauração da autoimagem e da sua função social faz com que sua experiência anterior com o câncer de mama seja colocada em segundo plano (DJOHAN; GAGE; BERNARD, 2008). 
Estudo de Alderman et al. (2008) que buscou compreender a influência do diálogo entre médico e paciente sobre as possibilidades de reconstrução mamária, durante o processo de decisão pelo tratamento do câncer de mama, concluiu que esse profissional deve estar apto a transmitir essas informações às pacientes, a fim de que elas sejam inseridas na decisão sobre seu tratamento. Essas opções devem se estender a todas as mulheres aptas a realizar tal cirurgia, independente de suas características sociodemográficas ou clínicas.

Para tal, é necessário que o profissional tenha conhecimento sobre a influência dos diferentes tipos de reconstrução mamária na vida da mulher que se submete a essa cirurgia, seus benefícios e as consequências negativas que ela pode acarretar.

Entendemos, portanto, que a compreensão da experiência da mulher com a reconstrução mamária possa gerar a elaboração de propostas para o atendimento humanizado voltado à mulher com câncer de mama. Um estudo desta natureza poderá fornecer subsídios para o desenvolvimento de novas pesquisas que contribuam para a ampliação do conhecimento sobre a temática. 
2. OBJETIVO 
Este estudo teve como objetivo compreender como é a experiência da reconstrução mamária na vida de mulheres com câncer de mama. 
3. $\mathcal{E M B \mathcal { A }} \mathcal{A} \mathcal{A M E \mathcal { N T O }}$ TEÓRICO 
Desde o início da civilização, a mulher assumiu o papel de cuidadora, responsável pelo bem-estar da família, o cuidado com a casa e a criação dos filhos. No entanto, sua imagem recatada, apagada e submissa sofreu modificações à medida que a mesma conquistava seu espaço na sociedade. Ela passou a assumir papéis antes desempenhados por homens e, ao tornar-se independente, tomou posse também do direito sobre seu corpo. As mudanças ocorridas, na forma como essa passou a se posicionar na sociedade, refletiram principalmente na forma como se via e como passava a ser vista.

Para Mauss (1974), assim como é responsável pela caracterização de uma cultura, o conjunto de costumes, crenças e tradições também se refere ao corpo.

A cultura desempenha papel fundamental na determinação dos atributos e dos costumes de cada gênero. Incluem-se em relação às mulheres, em certas culturas, as representações de gênero do corpo feminino, comportamento sexual, nascimento e reprodução. Homens e mulheres possuem a forma do corpo diferente e são socializados de modo distinto; as mulheres menstruam, engravidam, têm filhos e amamentam - os homens não (SOUZA, 2007).

O corpo feminino é fragmentado nos seus símbolos (mama, vagina), símbolos esses que o diferenciam do corpo masculino, e “cercam” a sua identidade enquanto pessoa na valorização do que a define enquanto mulher, sobretudo na nossa sociedade onde se enaltece o corpo feminino perfeito e erótico (AUGÉ, 1992, p. 122).

A mama da mulher, mais desenvolvida que a do homem, é parte do corpo estreitamente ligada à feminilidade e constitui um diferencial entre homem e mulher.

Ao longo dos séculos, a mama feminina adquiriu significados diversos, sendo por vezes considerada objeto de desejo, ao receber uma conotação sexual, quando representando tradicionalmente um ponto de vista masculino. Porém, ao longo de toda a história, a mama também foi dignificada por produzir o leite, fonte de alimento para a criança, sendo a mulher lactante vista como alguém capaz de promover o bem-estar geral do seu lar (YALON, 1997).

Com o fortalecimento da indústria, a partir do século XIX, diversos produtos foram fabricados com o intuito de apoiar, dar forma e aumentar as mamas. Os espartilhos, sutiãs, cremes, implantes de silicone e diversos outros artigos tornaram-se acessíveis a mulheres de todas as classes sociais (YALON, 1997).

No início dos anos de 1920, as mamas não eram enfatizadas e era comum serem ocultadas ou comprimidas por vestimentas recatadas. Já nos anos de 1950, mamas fartas eram sinônimo de sensualidade, e as mulheres dessa época exibiam decotes generosos que, com o uso de espartilhos, valorizavam seu volume e contorno (YALOM, 1997). 
O movimento de libertação das mulheres ocorrido nos anos de 1960 teve como marco o ato de queimar os sutiãs que se tornaram símbolo do paradigma de resistência frente às restrições externas. As mulheres começaram a participar de decisões sobre seu próprio corpo, como no caso da opção pela não amamentação, até a de realizar ou não a mastectomia em casos de câncer de mama (YALOM, 1997).

A partir do final do século XX e início do século XXI, evidenciou-se a centralidade adquirida pelo corpo para determinados segmentos sociais, destacando-se nesse período, o culto ao corpo como verdadeira obsessão. Este fato pode explicar o aumento significativo na quantidade de estudos científicos sobre a singularidade do corpo e a construção do gênero na cultura brasileira (GOLDENBERG, 2005).

Para Yalom (1997):

As mulheres têm sido obrigadas a confrontar o importante significado do
seio como fonte de vida e aniquilador. Por um lado, os seios estão associados
à transformação da adolescência para a idade adulta, ao prazer sexual e ao
aleitamento. Por outro, estão cada vez mais associados ao câncer de mama e
à morte. Para as mulheres, a oposição entre o seio "bom” e o seio "mau” não
põe em confronto a mulher e a santa com a vagabunda e a prostituta, como
acontece em muitos textos escritos por homens. Nem evoca a oposição entre
as percepções do seio "bom” e acalentador para a criança e o seio “mau” e
rejeitador, subjacentes a algumas teorias psicanalíticas. Para as mulheres, os
seios encarnam literalmente a tensão existencial entre Eros e Thanatos - vida
e morte - numa forma visível e palpável. (pág. 18-19)

No Brasil, o corpo sem marcas indesejáveis como rugas, celulites, estrias e manchas e sem excessos como gordura e flacidez é o único que mesmo sem roupas está decentemente vestido (GOLDENBERG, 2002). Nesse contexto, Goldenberg conclui que o corpo não só é mais importante que a roupa, mas sim, visto como a verdadeira roupa, havendo nele a necessidade de se exibir, moldar, manipular, trabalhar, costurar, enfeitar, escolher, construir, produzir e imitar, sendo a roupa, neste caso, vista apenas como um acessório para expor e valorizar esse corpo.

Há uma grande dificuldade em se pesquisarem questões relacionadas ao corpo, tendo em vista que a maioria de nós não se sente confortável para falar sobre o próprio corpo, sendo este um dos problemas antropológicos da experiência do corpo e da doença (AURELIANO, 2009).

Os sentimentos gerados de que nosso corpo é meramente um conjunto de partes, e que estas partes são propriedade de outras pessoas, são intensificados pelo tratamento que recebemos dos médicos quando algo dá errado... Se detectarmos um nódulo na mama, espera-se que nós o entreguemos nas mãos do profissional da medicina. O seio que nós 
aprendemos a associar à nossa sexualidade de repente se torna completamente dispensável (SPENCE, 1995, p.125).

Estudo acerca das representações e significados que o câncer adquire no decorrer do tempo em nossa cultura, de modo geral, enfatiza que a percepção socialmente construída da doença pode repercutir na forma como o doente irá vivenciá-la (GOMES; SKABA; VIEIRA, 2002).

Aureliano (2009) mostrou que a principal preocupação das mulheres com câncer de mama, quando souberam do diagnóstico, foi perder a mama, “ficar defeituosa”.

Em pesquisa nacional, realizada com 3.000 homens e mulheres sobre a vida sexual dos brasileiros, Abdo (2004) observou que, no caso das mulheres, um dos maiores problemas identificados foi a falta de desejo. Grande parte das mulheres entrevistadas não sentia vontade de ter relações, sendo um dos principais motivos para sua falta de desejo, a angústia de não corresponder à imagem de mulher com corpo perfeito, observado na mídia. De acordo com Abdo (2004), com a impossibilidade de exibir esse padrão, o desejo é reprimido aos poucos até desaparecer ou cercar-se de neuroses.

Para as mulheres que fazem reconstrução mamária, a transformação em seus corpos ainda será constantemente negociada já que se trata de um corpo modificado e reconstruído (AURELIANO, 2009).

Em seu estudo com mulheres mastectomizadas, Aureliano (2009) observou que para as mesmas a reconstrução era, em muitos casos, percebida e sentida como mais uma mutilação (quando realizada com músculos e tecido do abdome) e, para algumas, representava um sofrimento inútil, visto que não seria pela melhoria da saúde, mas da estética e da vaidade.

A mulher acometida pelo câncer de mama não só tem de lidar com a doença, seu tratamento e possíveis sequelas físicas e psicológicas, como também de se confrontar com os aspectos culturais que determinam a construção da identidade feminina, os quais certamente estarão envolvidos na relação com a doença que possui uma história, uma simbologia e um significado social (SILVA, 2008).

Esse contexto possibilita a reflexão a respeito da relação da mulher com a mama e da importância da mesma na construção da autoimagem. Sendo assim, pensar a mulher com câncer de mama coloca em discussão todos os conceitos anteriormente expostos e quais as consequências que essa patologia acarreta à sua autoimagem e autoestima. 
4. TRAJETÓRIA METODOLÓGICA 


\subsection{Desenho do estudo}

Trata-se de um estudo descritivo, com abordagem qualitativa.

A pesquisa descritiva é aquela na qual o pesquisador observa, registra, analisa e correlaciona fatos e fenômenos, sem interferir no objeto investigado (POLIT; HUNGLER, 1995; BARROS; LEHFELD, 1986).

Apesar de ter sido vista por muito tempo como um método de pesquisa de pouca validade científica, a abordagem qualitativa tem agora ganhado espaço na prática de pesquisa e seu uso tem sido bastante expressivo em estudos no campo da saúde.

Por meio de diversos métodos de investigação, as pesquisas qualitativas destinam-se ao estudo de um fenômeno no local em que ocorre, procurando tanto encontrar o sentido desse fenômeno, como interpretar os significados que as pessoas dão a eles (CHIZZOTTI, 2003).

Compreender a experiência da reconstrução mamária pós-câncer de mama, para as mulheres que se submeteram a esse procedimento, pressupõe o entendimento do fenômeno em sua profundidade. Para tanto, a pesquisa qualitativa mostra-se adequada a este estudo por permitir a flexibilidade necessária para que os próprios sujeitos sejam capazes de apontar os aspectos, relacionados à reconstrução, que julgarem relevantes.

\subsection{Local do estudo}

Este estudo foi realizado no Núcleo de Ensino, Pesquisa e Assistência na Reabilitação de Mastectomizadas (REMA), criado em 1989, por docentes da Escola de Enfermagem de Ribeirão Preto- USP, com o intuito de oferecer à mulher com câncer de mama o apoio necessário à sua reabilitação integral, abordando os aspectos físicos, emocionais e psicossociais, oferecidos por uma equipe multiprofissional.

As mulheres geralmente chegam ao Núcleo por encaminhamento ou aconselhamento de profissionais que atuam no setor de oncologia do Hospital das Clínicas da Faculdade de Medicina de Ribeirão Preto da Universidade de São Paulo, mas há também aquelas que vêm encaminhadas de outros serviços ou mesmo por indicação de mulheres que já participam do REMA.

Nesse serviço, as mulheres recebem atendimento multiprofissional e realizam atividades que as ajudam a superar as sequelas físicas e emocionais da doença, por meio de exercícios para prevenção e controle de linfedema e de limitações de amplitude de movimentos de braço e ombro, drenagem linfática, enfaixamento, estimulação elétrica de alta 
voltagem, além dos grupos verbais, nos quais elas encontram espaço para troca de experiências e solução de dúvidas a respeito do adoecer por câncer.

Também são realizados passeios, eventos comemorativos e feiras de artesanato, organizados pela equipe e pelas próprias usuárias.

O REMA foi escolhido como local deste estudo por oferecer assistência integral às mulheres com câncer de mama e também por facilitar o contato com aquelas que se enquadraram no perfil desta pesquisa.

O fato de estar colaborando com a equipe multiprofissional que atua no REMA facilitou a comunicação com as participantes desta pesquisa, o que contribuiu também na execução do projeto.

\subsection{Participantes do estudo}

Por se tratar de estudo de natureza qualitativa, o número de mulheres participantes não foi predeterminado, definindo-se ao longo da coleta dos dados, ou seja, à medida que foi ocorrendo repetição de conteúdos completou-se a coleta. Para essa abordagem, o critério fundamental não foi o quantitativo e, sim, sua possibilidade de incursão (MINAYO, 2006).

O REMA conta com 1.103 usuárias cadastradas, sendo que 93 destas realizaram a reconstrução mamária. Para seleção das mulheres, foram identificadas pelo sistema de cadastramento as que se enquadravam nos critérios de inclusão deste estudo: estar cadastrada no REMA; ter mais de 18 anos, ter sido submetida à cirurgia de reconstrução mamária póscirurgia por câncer de mama; estar apta a expressar-se verbalmente.

Após essa seleção, as participantes foram escolhidas de forma aleatória e, ao total, participaram da pesquisa 14 mulheres. É importante ressaltar que todas as que foram convidadas aceitaram participar da pesquisa.

\subsection{Aspectos éticos}

Foram respeitados todos os aspectos éticos contidos na Resolução 196/96 do Conselho Nacional de Saúde-CNS (BRASIL, 2009). O projeto somente foi iniciado após autorização do serviço e aprovação pelo Comitê de Ética em Pesquisa da Escola de Enfermagem de Ribeirão Preto da Universidade de São Paulo (protocolo 1168/2010). 
Todas as participantes do estudo foram esclarecidas quanto ao anonimato e sigilo das informações, a liberdade para interromper a participação na pesquisa caso desejassem, sem que isso lhes acarretasse qualquer tipo de dano. Foram também esclarecidas sobre os objetivos do estudo e que os dados obtidos seriam utilizados para elaboração de trabalho científico.

Após aceitarem participar da pesquisa, foi solicitado às participantes que assinassem o Termo de Consentimento Livre e Esclarecido (Apêndice A) no qual estava inclusa a autorização para a gravação das entrevistas, sendo que uma via do Termo de Consentimento ficou com a pessoa entrevistada e outra com a pesquisadora.

As fitas com a gravação das entrevistas foram transcritas na íntegra e serão arquivadas por cinco anos. Após esse período serão inutilizadas, conforme recomendação da Resolução $n^{\circ} 196 / 96$ sobre pesquisa envolvendo seres humanos (BRASIL, 2009).

Para garantia do sigilo com relação à identidade das participantes, foram atribuídos a cada uma, em ordem de ocorrência das entrevistas, nomes fictícios, em ordem alfabética. À primeira entrevistada foi dado um nome iniciado pela letra A (Anita), à segunda entrevistada, um nome que iniciava com a letra B (Bruna), à terceira, um nome com a inicial C (Carla), e assim por diante.

\subsection{Procedimento de coleta dos dados}

Inicialmente, foi consultado o banco de dados do REMA para seleção das mulheres que contemplavam os critérios de inclusão na amostra. Concluída esta etapa, o convite para participar da pesquisa foi realizado durante os dias e horários de atendimento do serviço ou por telefone. As entrevistas foram agendadas em locais e horários de preferência das usuárias. Sendo assim, duas entrevistas foram realizadas no local de trabalho das mesmas, sete foram realizadas no domicílio e cinco na Escola de Enfermagem de Ribeirão Preto, em salas reservadas.

Realizaram-se entrevistas semiestruturadas, gravadas e transcritas na íntegra para início imediato da codificação dos dados. Um diário de campo foi utilizado como recurso para anotações complementares com o propósito de auxiliar na interpretação dos dados. Desse modo, as notas de campo, desenvolvidas durante as entrevistas, forneceram subsídios para a compreensão do contexto no qual as entrevistadas se inseriam e seu modo de agir e reagir às questões que lhes eram feitas, auxiliando, portanto, na compreensão de sentidos implícitos nas falas. 
As entrevistas foram guiadas por um roteiro (Apêndice B) elaborado pela autora do estudo. O referido roteiro foi dividido em duas partes:

- Parte A - dados de caracterização das participantes do estudo (idade, estado civil, ocupação, tempo decorrido da cirurgia, entre outros);

- Parte B - questão disparadora: "Conte-me como foi para você realizar a reconstrução mamária”

Nesta investigação, a questão disparadora apenas direcionou o ponto do estudo explorado. Novas questões eram acrescentadas com o intuito de esclarecer e fundamentar a experiência.

Cada entrevista teve duração de aproximadamente 60 minutos. Inicialmente era feita a questão disparadora sobre como havia sido para elas a realização da cirurgia reconstrutora e, daí por diante, as entrevistas não seguiam uma sequência preestabelecida, ficando a critério das entrevistadas o direcionamento das mesmas. As mulheres falaram livremente sobre o processo de reconstrução, ressaltando pontos relevantes, como o fator determinante de sua escolha pela cirurgia reconstrutora, sentimentos diante do diagnóstico e da perda da mama e diversos outros pontos comuns que determinaram a construção das categorias.

Em pesquisa qualitativa, a entrevista caracteriza-se pela flexibilidade que possibilita um contato mais íntimo entre o entrevistador e o entrevistado e a exploração em profundidade de seus saberes, suas representações, suas crenças e valores. Para obter melhor compreensão da realidade social, o direcionamento da entrevista pode ser ampliado, considerando sempre as necessidades do projeto, ou seja, do objeto da pesquisa (LAVILLE; DIONNE, 1999).

As entrevistas foram realizadas no período de dezembro de 2010 a agosto de 2011.

Antes da aplicação do instrumento de coleta de dados, o mesmo foi submetido à avaliação de profissionais de saúde que prestam assistência às mulheres que frequentam o Núcleo de Reabilitação. As sugestões de mudanças foram acatadas e realizadas.

\subsection{Procedimento de análise dos dados}

Para a análise dos dados, optou-se pela Análise de Conteúdo, mais especificamente, a Análise Temática proposta por Bardin (1979), descrita por Minayo (2006). Dentre as diversas técnicas para Análise de Conteúdo, a Análise Temática é a que mais se adapta à análise de 
dados qualitativos em saúde. Esse tipo de técnica vai além da denominação de procedimento técnico, é parte de uma busca teórica e prática no que diz respeito às investigações sociais (MINAYO, 2006).

A Análise de Conteúdo, enquanto técnica de tratamento de dados, é derivada das metodologias quantitativas e busca sua lógica na interpretação do material de caráter qualitativo. Nesse tipo de análise, busca-se desconstruir a fala e buscar o "que está por trás dos conteúdos manifestos” (MINAYO 2006).

Minayo (2006) explica que a análise temática consiste em descobrir os núcleos de sentido que integram uma comunicação, considerando-se que sua presença ou frequência tenham algum significado para o objeto analítico esperado. Esse tipo de análise se dá pela contagem de frequência das unidades de significado.

De acordo com Bardin (1979, p. 105), “Tema é a unidade de significação que se liberta naturalmente de um texto analisado segundo critérios relativos à teoria que serve de guia à leitura”.

Minayo (2006) descreve as três etapas do procedimento de análise temática propostas por Bardin (1979): pré-análise, exploração do material e tratamento dos resultados obtidos e interpretação, os quais foram obedecidos durante a análise dos dados deste estudo.

Na pré-análise, os documentos a serem analisados são escolhidos e há a retomada das hipóteses e dos objetivos iniciais da pesquisa. O investigador questiona-se sobre as etapas realizadas e as relações entre as mesmas, elaborando indicadores que irão orientá-lo na compreensão do material e na interpretação final dos dados. A pré-análise pode ser dividida nas seguintes tarefas:

Leitura flutuante: nesta etapa, o pesquisador entra em contato direto e intenso com o material, deixando-se impregnar pelo seu conteúdo. É necessário que haja a dinâmica entre as hipóteses iniciais, as teses emergentes e as teorias relacionadas ao tema, a fim de que a leitura possa se tornar progressivamente mais sugestiva, diminuindo a sensação de desorganização gerada no início da análise.

Constituição do corpus: refere-se ao universo estudado em sua totalidade e deve responder a algumas normas de validade qualitativa: exaustividade: o material deve conter todos os aspectos levantados no roteiro; representatividade: o material deve conter as características essenciais do universo pretendido; homogeneidade: deve-se obedecer a critérios precisos de escolha quanto aos temas, às técnicas empregadas e aos atributos dos interlocutores; pertinência: os documentos analisados devem ser adequados para responder aos objetivos do trabalho. 
Formulação e reformulação de hipóteses e objetivos: consiste em processo no qual se retoma a etapa exploratória, realizando-se a leitura exaustiva do material, tendo como base os questionamentos iniciais. Há também a reformulação de hipóteses, o que pode levar à correção de rumos interpretativos ou a novas indagações.

Como previsto para a pré-análise, houve a determinação das unidades de registro (palavra-chave ou frase), das unidades de contexto (compreensão do contexto da unidade de registro), dos recortes, da forma de categorização, da modalidade de codificação e dos conceitos teóricos gerais que orientaram a análise, representados no quadro a seguir: 


\begin{tabular}{|c|c|}
\hline UNIDADES DE REGISTRO & UNIDADES DE CONTEXTO \\
\hline $\begin{array}{l}\text { Olha, quando eu soube que ia ter que fazer o } \\
\text { quadrante, tudo é o que eu falei, eu fiquei } \\
\text { bastante chateada, triste porque o câncer ele já } \\
\text { tem um sinônimo, uma cultura da gente de morte, } \\
\text { é uma sentença de morte... na cabeça da gente o } \\
\text { câncer ainda é uma coisa devastadora... (Bruna) }\end{array}$ & -Vendo o câncer como uma doença devastadora. \\
\hline $\begin{array}{l}\text {...e eu então logo que ele já me falou: vou retirar } \\
\text { o... vou fazer o quadrante, a minha preocupação } \\
\text { já foi essa daí, de fazer a reconstrução. Eu já tive } \\
\text { essa preocupação, de fazer pra não ficar com um } \\
\text { buraco na mama, a gente sabe... eu falei pra ele } \\
\text { que se fizesse o quadrante se ele fizesse uma } \\
\text { reconstrução... (Bruna) }\end{array}$ & -Pedindo para o médico fazer a reconstrução. \\
\hline $\begin{array}{l}\text {...porque isso faz parte, faz parte da sexualidade } \\
\text { da gente. A mama, ela faz parte de um monte de } \\
\text { coisa e a gente tem muita sensibilidade na mama. } \\
\text { Mesma coisa, na sexualidade ela tem bastante } \\
\text { sensibilidade. Quando me toca eu sinto bastante } \\
\text { e agora tá meio comprometido. (Bruna) }\end{array}$ & $\begin{array}{l}\text {-Vendo sua sexualidade comprometida pela } \\
\text { perda de sensibilidade. }\end{array}$ \\
\hline $\begin{array}{l}\text {...então eu não vou deixar de ter minha vida } \\
\text { sexual, de ter meu parceiro, de namorar por } \\
\text { causa da minha mama. Ela me faz falta? A minha } \\
\text { sensibilidade, faz bastante, mas eu não posso } \\
\text { deixar de viver por causa desse probleminha. Eu } \\
\text { tenho que buscar outros meios pra mim viver, } \\
\text { tenho que buscar outras formas, entendeu? } \\
\text { (Bruna) }\end{array}$ & $\begin{array}{l}\text {-Buscando outros meios de compensar a perda de } \\
\text { sensibilidade da mama. }\end{array}$ \\
\hline $\begin{array}{l}\text {...ela se vê bonita, olha lá, vê o seio dela lá, você } \\
\text { entendeu? Aí que você fala assim, poxa, eu achei } \\
\text { que fosse o câncer tirar, tal,tal, mas eu tô vendo } \\
\text { a minha mama aqui, tá aqui, então quer dizer } \\
\text { que não vai modificar tanto assim a expressão } \\
\text { corporal dela. (Bruna) }\end{array}$ & $\begin{array}{l}\text {-Vendo a reconstrução como chance de diminuir } \\
\text { as mudanças causadas pelo câncer. }\end{array}$ \\
\hline
\end{tabular}

Quadro 1 - Exemplo de interpretação das falas na pré-análise dos dados 
Na fase de exploração do material ocorreu a operação classificatória, buscando-se alcançar o núcleo de compreensão do texto. Nessa etapa, houve a formação de categorias que são expressões ou palavras significativas em função das quais o conteúdo de uma fala é organizado. Tradicionalmente, esta fase é trabalhada primeiro e nela o texto é recortado em unidades de registro indicadas como relevantes na pré-análise. Em seguida, iniciou-se a contagem, buscando-se a compreensão do conteúdo dos relatos por meio de codificações e índices quantitativos. Seguiram a esta fase a classificação e a agregação dos dados, escolhendo-se as categorias teóricas ou empíricas, responsáveis pela especificação dos temas.

$\mathrm{O}$ quadro a seguir traz os dois temas que emergiram dos relatos e as respectivas categorias e subcategorias responsáveis pela especificação desses temas: 


\begin{tabular}{|c|c|c|}
\hline TEMAS & CATEGORIAS & SUBCATEGORIAS \\
\hline \multirow{4}{*}{$\begin{array}{c}\text { DO DIAGNÓSTICO À } \\
\text { DECISÃO PELA } \\
\text { RECONSTRUÇÃO } \\
\text { MAMÁRIA }\end{array}$} & $\begin{array}{l}\text { Sentimentos diante do } \\
\text { diagnóstico }\end{array}$ & \\
\hline & & \\
\hline & \multirow{2}{*}{$\begin{array}{l}\text { Fatores determinantes } \\
\text { na opção pela } \\
\text { reconstrução mamária }\end{array}$} & $\begin{array}{l}\text { O desejo de não se ver sem } \\
\text { mama }\end{array}$ \\
\hline & & A influência do médico \\
\hline \multirow{7}{*}{$\begin{array}{l}\text { A EXPERIÊNCIA PÓS- } \\
\text { RECONSTRUÇÃO }\end{array}$} & \multirow{2}{*}{$\begin{array}{l}\text { Os benefícios da } \\
\text { reconstrução mamária }\end{array}$} & $\begin{array}{l}\text { A recuperação da } \\
\text { autoimagem }\end{array}$ \\
\hline & & A superação da doença \\
\hline & \multirow{3}{*}{$\begin{array}{c}\text { Os problemas } \\
\text { ocasionados pela } \\
\text { cirurgia }\end{array}$} & $\begin{array}{c}\text { A insatisfação com o aspecto } \\
\text { da nova mama }\end{array}$ \\
\hline & & $\begin{array}{l}\text { O medo de perder a mama } \\
\text { novamente }\end{array}$ \\
\hline & & $\begin{array}{l}\text { A perda da sensibilidade da } \\
\text { mama }\end{array}$ \\
\hline & Redes de apoio à & $\begin{array}{c}\text { O papel da família e dos } \\
\text { amigos }\end{array}$ \\
\hline & mulher & O apoio do REMA \\
\hline
\end{tabular}

Quadro 2: Temas, categorias e subcategorias resultantes da análise dos dados

$\mathrm{Na}$ última etapa, que consiste no tratamento dos resultados obtidos e na interpretação, houve a proposição de inferências e a realização de interpretações interrelacionando-as com a literatura pertinente à temática estudada. 


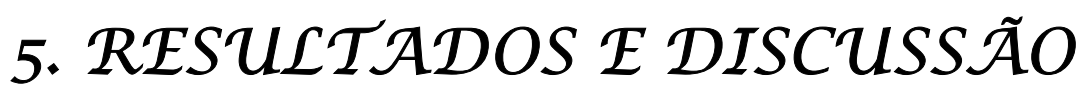




\subsection{Conhecendo as mulheres do estudo}

A idade das participantes variou entre 42 e 60 anos. Quanto ao estado civil, sete delas eram casadas, quatro, divorciadas, duas, solteiras e uma vivia em união consensual com o companheiro. Sete mulheres tinham vínculo empregatício, duas eram trabalhadoras autônomas, duas eram do lar e três, aposentadas. Em relação ao grau de escolaridade, duas possuíam Ensino Fundamental incompleto, seis haviam completado o Ensino Médio, duas possuíam Ensino Superior incompleto, três haviam concluído o Ensino Superior e uma havia realizado pós-graduação.

O tempo de diagnóstico de câncer de mama variou entre dois e 16 anos e o de realização da cirurgia para retirada do câncer variou entre um e 16 anos.

O tempo de realização da reconstrução mamária variou entre um e 13 anos, e o tipo de cirurgia mais frequente foi a reconstrução com prótese de silicone, com um total de sete mulheres que a realizaram, sendo que uma destas utilizou expansor antes da colocação da prótese. Cinco mulheres realizaram a cirurgia reconstrutora com retalho do Músculo Reto do Abdômen (TRAM) e duas mulheres fizeram reconstrução com retalho obtido do músculo Grande Dorsal com uso concomitante da prótese de silicone.

Em relação ao momento da realização da cirurgia reconstrutora, dez mulheres haviam sido submetidas à reconstrução imediata (no mesmo ato cirúrgico da retirada da mama) e quatro à reconstrução tardia (meses ou anos após a cirurgia para retirada da mama).

Apesar de a reconstrução mamária para mulheres submetidas a cirurgias para câncer de mama ser oferecida gratuitamente pelo Sistema Único de Saúde desde 1999, apenas oito das 14 mulheres realizaram a reconstrução pelo SUS. Cinco mulheres finalizaram a reconstrução da mama.

Com a finalidade de proporcionar melhor compreensão dos contextos nos quais as mulheres que fizeram parte deste estudo se inseriam, é apresentada a seguir, uma breve caracterização de cada uma delas:

\section{Anita (S1)}

Anita tem 42 anos, é casada e tem dois filhos, possui Ensino Médio completo e é oficial administrativa. Descobriu o câncer de mama aos 31 anos e foi submetida a uma mastectomia do tipo Halsted na mama esquerda, em 1999. Utilizou durante três anos a prótese mamária externa e passou por uma situação constrangedora quando perdeu essa prótese no mar, o que a 
levou a procurar o médico para realizar a reconstrução mamária. Foi submetida à reconstrução mamária com Retalho do Músculo Transverso do Abdome (TRAM), em 2002. A cirurgia foi feita pelo convênio médico e foi realizada a finalização com a formação do complexo aréolomamilar. Anita frequenta o REMA desde 2009.

\section{Bruna (S2)}

Bruna tem 52 anos, é divorciada e tem três filhos, possui Ensino Médio completo e é empregada doméstica. Descobriu o câncer de mama aos 48 anos e, desde então, passou por diversas cirurgias para retirada de tumores, porém diz que estas cirurgias deixaram sua mama deformada e, em 2009, três anos após descobrir a doença, sofreu uma quadrantectomia na mama esquerda. Por iniciativa própria, foi submetida a uma reconstrução mamária imediata com retalho obtido do Músculo Grande Dorsal. A reconstrução foi realizada pelo SUS e ainda não foi feita a finalização da cirurgia. Bruna frequenta o REMA desde 2009.

\section{Carla (S3)}

Carla tem 56 anos, é divorciada e tem três filhos, possui Ensino Superior completo e é professora aposentada. Recebeu o diagnóstico de câncer de mama aos 52 anos. Em 2007, foi submetida a uma quadrantectomia e, em 2010, teve uma recidiva, sendo submetida à mastectomia do tipo Madden bilateral e à reconstrução mamária imediata com implante de prótese de silicone. A reconstrução, sugerida pelo médico, foi realizada pelo convênio médico e não houve necessidade de finalização da cirurgia, pois foram preservados ambos os complexos aréolo-mamilares. Carla frequenta o REMA desde 2010.

Denise (S4)

Denise tem 53 anos, é casada e não tem filhos, possui Ensino Médio completo e é auxiliar de serviços gerais. Em 2002, aos 45 anos, foi submetida a uma mastectomia do tipo Madden na mama esquerda e, por sugestão do médico, à reconstrução mamária imediata com implante de prótese de silicone. Sua família a estimulou a fazer a reconstrução e inclusive comprou a prótese. A cirurgia reconstrutora foi feita pelo SUS e ainda não foi finalizada. Denise começou a frequentar o REMA em 2002 logo depois de realizar a cirurgia, porém, no momento está afastada do serviço, pois relata falta de tempo depois que voltou a trabalhar. 
Eva (S5)

Eva tem 53 anos, é solteira e tem duas filhas, possui Ensino Médio completo e é auxiliar de enfermagem aposentada. Em 1995, aos 37 anos, recebeu o diagnóstico de câncer de mama e foi submetida a uma mastectomia do tipo Patey na mama esquerda. Utilizou durante muito tempo a prótese mamária externa e oito anos após a cirurgia para retirada da mama, por insistência do médico, resolveu se submeter a uma reconstrução mamária tardia com retalho do Músculo Transverso do Abdome (TRAM). A reconstrução foi realizada pelo SUS, e a cirurgia ainda não foi finalizada. Eva frequenta o REMA desde 1995.

\section{Fátima (S6)}

Fátima tem 47 anos, é casada e tem dois filhos, possui Ensino Médio completo e é oficial administrativa. Recebeu o diagnóstico de câncer de mama aos 43 anos. Em 2007, quando recebeu o diagnóstico, foi submetida a uma mastectomia do tipo Madden na mama direita. $\mathrm{O}$ médico propôs a reconstrução imediata da mama e a mesma foi realizada com implante de prótese de silicone, seguida por plástica de redução da mama contralateral. As cirurgias foram realizadas pelo SUS e a reconstrução ainda não foi finalizada. Fátima começou a frequentar o REMA em 2007, porém, não está frequentando o serviço no momento, já que o horário coincide com o de seu emprego.

\section{Gisele (S7)}

Gisele tem 53 anos, é divorciada e tem dois filhos, possui Ensino Superior incompleto e é do lar. Descobriu que tinha câncer de mama, em 2005, aos 47 anos. Foi submetida a mastectomias do tipo Madden bilaterais. A reconstrução foi sugerida pelo médico e imediata à mastectomia. Foram utilizados retalho do Músculo Transverso do Abdome (TRAM) em uma das mamas e prótese de silicone para a reconstrução da mama contralateral. A reconstrução foi feita por convênio médico e houve a finalização da cirurgia com a formação do complexo aréolo-mamilar em uma das mamas, na outra mama o mesmo foi preservado durante a mastectomia. Gisele começou a frequentar o REMA em 2010, porém, não está mais frequentando o núcleo, pois relata falta de tempo disponível.

\section{Hilda (S8)}

Hilda tem 59 anos, é divorciada e tem três filhos, possui pós-graduação e é enfermeira aposentada. Foi diagnosticada com câncer de mama aos 57 anos e, em 2009, foi submetida a uma mastectomia do tipo Patey na mama esquerda. A reconstrução foi sugerida pelo médico e 
realizada imediatamente após a mastectomia. Foi utilizada prótese de silicone para a reconstrução da mama. A mesma foi realizada pelo SUS e não foi finalizada. Hilda começou a frequentar o REMA em 2009, porém não frequenta mais o serviço pelo fato de o mesmo ser distante da sua casa e por estar realizando sessões particulares de fisioterapia.

\section{Ivone (S9)}

Ivone tem 56 anos, vive em uma união consensual e tem dois filhos, possui Ensino Fundamental incompleto e é do lar. Em 1998, aos 43 anos teve câncer de mama, foi submetida a uma quadrantectomia na mama esquerda e à reconstrução mamária imediata, porém um fato interessante é que, durante todo o tratamento, não lhe foi informado o diagnóstico de forma aberta. Ela refere ter recebido o diagnóstico de carcinoma e o aceitou, sem saber o significado da palavra. Concordou com a mastectomia e a reconstrução da mama sem ao menos saber que estava com câncer e, segundo ela, se tivesse conhecimento da doença no momento do diagnóstico e já tivesse conhecido mulheres com reconstrução antes, não aceitaria fazer cirurgia reconstrutora da mama. A reconstrução imediata foi sugerida pelo médico e foi utilizada prótese de silicone. A cirurgia foi realizada pelo SUS e houve finalização da mesma. Ivone frequenta o REMA desde 1999.

\section{Joana (S10)}

Joana tem 44 anos, é casada e tem três filhos, possui Ensino Fundamental incompleto e é trabalhadora autônoma. Em 2004, aos 37 anos, recebeu o diagnóstico de câncer de mama e foi submetida a uma mastectomia do tipo Madden na mama direita. Usou a prótese mamária externa durante um ano e então decidiu submeter-se à reconstrução mamária. A reconstrução foi realizada, em 2005, e foi utilizada prótese de silicone. O médico foi também neste caso, fator importante no processo de decisão pela cirurgia visto que ofereceu apoio, inclusive garantindo que Joana recebesse do SUS, além da cirurgia, a prótese de silicone. A cirurgia reconstrutora ainda não foi finalizada. Joana frequenta o REMA desde 2005.

\section{Karen (S11)}

Karen tem 52 anos, é casada e tem dois filhos, possui Ensino Superior completo e é enfermeira. O primeiro diagnóstico de câncer de mama foi aos 43 anos, em 2002. Foi realizada uma nodulectomia na mama direita e a reconstrução imediata da mama com prótese de silicone. No entanto, quatro anos depois das cirurgias, notou que havia uma vermelhidão ao redor da cicatriz cirúrgica e após exames foi constatada recidiva local do câncer. Foi 
submetida então a uma mastectomia do tipo Madden na mama direita e novamente à reconstrução imediata da mama, agora com retalho do Músculo Transverso do Abdome (TRAM). As cirurgias reconstrutoras foram sugeridas pelo médico e realizadas pelo convênio médico. A última cirurgia não foi finalizada. Karen frequenta o REMA desde 2006.

\section{Luísa (S12)}

Luísa tem 47 anos, é casada e tem dois filhos, possui Ensino Médio completo e é telefonista. Quando recebeu o diagnóstico de câncer de mama, em 2007, tinha 44 anos. Dois anos depois do diagnóstico, foi submetida a uma mastectomia do tipo Madden na mama esquerda e a uma quadrantectomia na mama direita. A reconstrução mamária foi imediata-tardia, pois foi implantado um expansor sob a pele que, posteriormente, foi substituído por uma prótese de silicone. A cirurgia reconstrutora foi feita pelo SUS e ainda não foi finalizada. Luísa está frequentando o REMA desde 2009.

\section{Marta (S13)}

Marta tem 53 anos, é solteira e não tem filhos, possui Ensino Superior incompleto e é costureira. Foi diagnosticada com câncer de mama com 51 anos, em 2008, e dois anos depois do diagnóstico foi submetida à mastectomia do tipo Madden na mama esquerda e à reconstrução imediata da mama. A reconstrução da mama foi sugerida pelo médico e foi realizada por meio do uso de retalho obtido do Músculo Grande Dorsal, juntamente ao implante de silicone. A cirurgia reconstrutora foi feita pelo SUS e ainda não foi finalizada. Marta começou a frequentar o REMA em 2010, porém, não está mais frequentando o serviço, pois alega falta de tempo disponível.

\section{Nair (S14)}

Nair tem 60 anos, é casada e tem uma filha, possui Ensino Superior completo e é do lar. Recebeu o diagnóstico de câncer de mama em 1994, aos 43 anos. Sua primeira cirurgia para retirada do câncer foi uma quadrantectomia na mama esquerda em 1994. Em 2002, houve uma recidiva da doença na mesma mama e Nair passou por uma segunda quadrantectomia. Em 2004, devido a uma segunda recidiva, foi submetida a uma mastectomia do tipo Patey na mama esquerda e, por sugestão do médico, foi realizada a reconstrução imediata da mama com retalho do Músculo Transverso do Abdome (TRAM). A reconstrução foi realizada pelo convênio médico e não houve finalização da mama. Nair frequenta o REMA desde 1995. 


\subsection{Imergindo nas entrevistas}

Os resultados foram divididos em dois temas principais. O primeiro aborda a experiência das mulheres entre o diagnóstico e a realização da cirurgia reconstrutora e agrupa categorias referentes aos sentimentos e atitudes das mulheres diante do diagnóstico de câncer de mama e como se deu o processo decisório pela reconstrução mamária. No segundo, as categorias estiveram relacionadas à forma como a mulher se vê depois da reconstrução e o que a mesma significou em sua vida, como ela percebe seus benefícios, como convive com as limitações decorrentes da cirurgia reconstrutora bem como o papel das diversas redes de apoio em sua trajetória.

\subsubsection{Do diagnóstico à decisão pela reconstrução mamária}

\section{Sentimentos diante do diagnóstico}

O câncer de mama causa grande temor na sociedade, principalmente entre as mulheres, já que apresenta elevado índice de morbidade e mutilação e pode promover o comprometimento da autoestima e do relacionamento social das pessoas que ele acomete (ARAÚJO; FERNANDES, 2008).

Pelo fato de o câncer ser uma doença carregada de estigmas e frequentemente associado à morte, o sentimento mais presente no momento do diagnóstico é o desejo de sobreviver. O medo de uma possível recidiva, ou até mesmo da morte, leva a mulher a aceitar a realização de uma cirurgia radical, com o intuito de livrar-se de forma definitiva da doença, sendo a perda da mama colocada em segundo plano.

Os conceitos que o indivíduo tem de seu próprio corpo são responsáveis pela formação de sua imagem corporal e esta imagem não é apenas física, mas também psicológica, social e cultural. A aceitação que muitas mulheres demonstram em perder a mama decorre do fato de essa perda ser inevitável, o único caminho para a cura tão esperada (ARAÚJO; FERNANDES, 2008; ALVES et al., 2010). Essa necessidade de "livrar-se da doença” é claramente expressa nas falas a seguir: 
“...porque na hora que eu tive, logo, eu queria sarar, eu queria viver, então eu disse: eu prefiro ficar sem a mama e ficar viva. De imediato.” (Fátima)

"Então ele (médico) viu se eu concordava e eu concordei, falei, é melhor tirar do que espalhar tudo, você quer mais é tirar a doença mesmo, quanto antes melhor, então não senti nada... eu achava que eu queria ser curada, então eu não liguei de ter tirado não." (Anita)

"Aí eu falei pra ele (médico), eu falei: olha, tô pronta! minha cabeça tá boa agora, não sei daqui a cinco anos como é que vai tá, daqui dois, três anos como que vai tá, aí ele resolveu fazer a retirada total... eu queria ficar boa, eu queria sarar. Então na minha cabeça tava assim: eu vou fazer e vou sarar! Então eu não fiquei pensando, ai vou ficar sem seio, ai meu cabelo vai cair.” (Denise)

Por muito tempo, a prática da medicina foi direcionada à visão fragmentada do doente. Via-se a doença sem corpo ou um corpo modificado dividido em partes, desconsiderando-se os elementos subjetivos relacionados à pessoa doente. Ao descobrir-se portadora de um câncer de mama, a mulher remete-se à questão da fragmentação, pois agora, aquela parte em torno da qual construiu suas representações de maternidade, sexualidade e feminilidade não é mais que uma parte mesmo, tornando-se, assim, completamente dispensável (AURELIANO, 2009).

A mama é vista como o objeto central de desejo e satisfação. Ao adquirir uma doença neste objeto, há a destruição de todas as possibilidades de simbolização da mulher enquanto ser feminino (ALVES et al. 2010). A partir do momento em que se liberta da possibilidade de morte, a mulher irá preocupar-se com a mutilação da mama e suas consequências (DUARTE; ANDRADE, 2003).

"É lógico que você quer que tira, porque você quer que tira a doença, mas também você não queria ficar sem ele(seio)...” (Anita)

“...a primeira vez que ele (médico) falou que ia tirar só a parte de dentro eu fiquei muito assustada... quando eu fiquei sabendo da segunda vez, que eu já sabia que ia ser mais difícil, eu sofri muito. É muito difícil. É difícil você perder a mama, é difícil você perder os cabelos. Nossa! é muito difícil. É um sofrimento intenso... porque a mama ela tem, esteticamente, é uma coisa muito importante no corpo.” (Karen)

Ao considerar-se o papel relevante atribuído à mama, espera-se que sua mutilação seja geradora de profundas repercussões negativas na autoestima, mesmo que tal procedimento seja primordial à preservação da vida. Sendo assim, dois tipos de perda estão ligados à mastectomia, a experiência da perda da mama e a da perda da feminilidade, relacionadas ao comprometimento da autoestima e dos sentimentos eróticos (TEIXEIRA, 2008).

É possível, então, perceber que o sofrimento que a mulher vivencia com o câncer de mama e seus tratamentos não está apenas relacionado à doença, mas também aos significados atribuídos à mesma ao longo da história e à sua cultura. É necessário, portanto, pensar em 
todos os aspectos relacionados ao câncer de mama, para que possa haver melhor qualidade nas propostas de atenção à mulher.

\section{Fatores determinantes na opção pela reconstrução mamária}

\section{O desejo de não se ver sem mama}

Apesar de o medo da morte no momento do diagnóstico ter sido frequente nas mulheres deste estudo, foi possível observar nos relatos de algumas delas a preocupação imediata com a retirada da mama e a busca de meios para amenizar essa perda. A notícia de que iria perder a mama foi tão impactante para a mulher quanto o diagnóstico de câncer. E a procura pela reconstrução, nesses casos, partia da própria mulher, que não se sentia preparada para perder um órgão necessário à aceitação do seu corpo.

Nesse sentido, estudo de Silva (2008) identificou que algumas mulheres, a princípio, preferiam a morte à perda da mama e pressupôs que a falta da mama representou para elas, num primeiro momento, a morte simbólica. As mulheres de seu estudo manifestaram intenso medo de rejeição do companheiro, filhos e outros familiares ou amigos.

A mama feminina representa o conceito que a mulher tem de si mesma, é vista como a comprovação da sua feminilidade e sexualidade. Portanto, o fato de perdê-la é visto como uma castração (ARAÚJO; FERNANDES, 2008).

O medo de não ter preparo para lidar com esse sentimento de castração foi o motivo pelo qual algumas mulheres que participaram deste estudo buscaram a reconstrução da mama, já que o câncer que ameaçava suas vidas passava também a ameaçar suas essências.

“...ele (médico) ia fazer a mastectomia, depois resolveram fazer o quadrante, e eu naquela preocupação que eu fiquei de ficar com aquele buraco na mama. A única preocupação que eu tinha, eu perguntei pra ele (médico) que se caso tivesse que tirar toda a mama, que ele me colocasse, me fizesse... colocasse um... como que fala?... a prótese né? Eu falei pra ele que se fizesse o quadrante que ele fizesse uma reconstrução. Mas assim mesmo me garantiram que iam colocar uma prótese porque isso era muito importante pra mim.” (Bruna)

“...pra uma pessoa que passa por uma mastectomia e não coloca prótese, ela tem que tá muito boa de cabeça pra poder aceitar a não colocação de uma prótese. Então, eu não tava preparada pra isso. Eu me acho nova pra isso, pra ficar sem uma prótese, sem nada... Quando o médico falou que eu tinha que fazer a mastectomia, a primeira coisa que eu perguntei pra ele foi o que que eu poderia tá fazendo pra substituir a mama. Então foi onde ele colocou a opção pra mim da reconstrução ou de implantar a prótese... o motivo que eu procurei colocar a prótese foi isso, porque eu acho que seria difícil eu me aceitar sem a prótese.”(Luisa) 
No caso de Bruna e Luísa, a prótese a que elas se referem é a prótese de silicone implantada cirurgicamente para a reconstrução mamária. Nem sempre a paciente com câncer pode fazer a reconstrução da mama, no momento da cirurgia, para a retirada do tumor. Algumas vezes é necessário aguardar a finalização da terapia adjuvante ou até mesmo o resultado de exames laboratoriais para que seja decidido se a mulher estará apta a realizar a cirurgia reconstrutora. Para essas mulheres, pode-se optar pelo uso da prótese externa, que é utilizada abaixo do sutiã e pode ser confeccionada com diversos tipos de materiais, como silicone, gel, extrato mineral ou poliuretano.

O incentivo ao uso de prótese externa é visto como uma tentativa de promover simetria e tornar a imagem corporal semelhante à anterior. Contudo, o processo de reintegração social deve considerar a paciente em sua singularidade, pois o uso desse tipo de prótese pode ser permeado por diversos incômodos e desconfortos, já que muitas mulheres referem que a prótese não se movimenta como a outra mama e há a necessidade de atenção constante para não se esquecer de usá-la. O uso constante da prótese é outro fator que diariamente remete a mulher ao fato de que seu corpo não é mais o mesmo e algo se alterou permanentemente após o câncer, o que pode aumentar o sentimento de angústia causado pela doença (JESUS; LOPES, 2003; SILVA; SANTOS, 2008).

Sendo assim, observa-se que o fato de a mulher sentir-se desconfortável com a prótese externa, muitas vezes é a causa da busca pela reconstrução mamária como um meio de obter uma mama semelhante à natural:

"Eu usava uma prótese externa, aquela que vai dentro do sutiã, aí eu punha ela... aí por isso que eu resolvi fazer depois, porque antes até eu não queria fazer a reconstrução, mas aí você vai na praia, aquilo lá um dia saiu, aí a gente fica zonza, meio sem saber o que fazer... eu pensava mais em tirar aquela prótese externa mesmo, minha preocupação era mais isso.” (Anita)

“...ah, às vezes é até melhor ficar sem (a prótese mamária externa), porque não adiantava nada, não adiantava muito. Tinha que tirar, por só pra sair, em casa eu não usava, mais era pra sair mesmo. Ela (prótese mamária externa) era muito ruim.” (Joana)

“...você vai na piscina, você põe um maiô, biquíni, alguma coisa, se você já com a prótese sempre aparece, sempre sai do lugar, fica marcado.” (Eva)

Como no caso de algumas mulheres deste estudo, muitas outras também não podem realizar a reconstrução mamária imediata devido à necessidade de tratamento adjuvante, sendo o uso da prótese externa a alternativa mais acessível. No entanto, como se observa nas falas acima, pode ocorrer dificuldade de adaptação a esta prótese. Esta dificuldade está 
geralmente relacionada ao fato de a mesma ser considerada pesada e quente e de haver a possibilidade de ocorrer incidentes como, por exemplo, seu deslocamento, o que pode causar grande embaraço em algumas mulheres (TEIXEIRA, 2008). Um bom exemplo desse tipo de situação pode ser observado no depoimento de Anita, que busca pela reconstrução quando passa por constrangimento ao utilizar tal prótese.

Nota-se que a prótese externa, muitas vezes, não foi incorporada à autoimagem da mulher, justamente por causar este desconforto com relação ao uso de roupas de maior exposição do corpo, como biquínis ou roupas decotadas. A prótese acaba por chamar mais atenção por proporcionar uma imagem disforme à mulher, ou pelo seu constante deslocamento ou por possuir tamanho e formato diferentes da mama natural.

\section{A influência do médico}

Apesar de haver diversos profissionais envolvidos no acompanhamento das mulheres deste estudo, independente da fase da doença, quando questionadas sobre a participação destes no processo de decisão pela reconstrução da mama, o médico foi o profissional lembrado por todas. O mesmo também foi apontado como o maior influenciador na realização da reconstrução mamária.

Foi possível observar que houve insegurança e medo no momento do diagnóstico e, diante do estresse que o câncer ocasionou, a mulher viu o médico como a única pessoa capaz de tomar as decisões corretas, depositando nele total confiança em relação ao seu tratamento. Sendo assim, o médico exerceu importante influência na decisão pela cirurgia reparadora e até mesmo, por perceber essa vulnerabilidade por parte da mulher, acabou sendo, muitas vezes, responsável pela escolha de tal procedimento.

Os depoimentos das mulheres deste estudo deixam evidente a confiança das mesmas nas decisões médicas, e a certeza de que o que estava sendo proposto era o melhor para elas naquele momento:

“...não escolhi nada, eu não escolhi nada. Ele (médico) falou que ele ia fazer a cirurgia, que ele ia rodar o retalho, foi falando o que ele ia fazer. Eu falei: tá bom. Eu fui concordando porque na verdade, nesse momento, você tá muito vulnerável. Na verdade parece que a gente não sabe muito bem o que é bom pra gente. Parece que ele (médico) tem mais... e tem mesmo... eu acho que a reconstrução é uma forma de nesse momento sofrido, de perda, de perda até de identidade, porque você parece que fica faltando um pedaço. Eu acho que a reconstrução, acho que os médicos, a equipe que tá atendendo, tem tido essa preocupação, que é uma preocupação importante, porque você tira a doença mas você também tem que pensar na outra questão, que é como a mulher vai se sentir depois disso." (Karen) 
“...Foi a equipe mesmo que me operou, então eu fui consultada, sugeriram, mediram. Foi iniciativa deles. Na verdade eu tô nessa área e eu nem achava que tivesse em seguida, mas eu acho que eu tive muita sorte... Foi sugestão deles mesmo de colocar. Na verdade eu não tava nem pensando direito. Então eu tava aceitando, tava na mão deles mesmo, então eu acho que escolhendo o melhor, eu aceitei." (Hilda)

É interessante observar como Karen e Hilda, duas enfermeiras, assumem nesse momento uma posição passiva, aceitando as propostas de tratamento oferecidas pelo médico por vê-lo como detentor do conhecimento necessário para decidir o que é melhor para elas nesse período em que as mesmas não acreditam ser capazes de decidir por si próprias.

Num momento em que a mulher está decidindo sobre os tratamentos necessários à manutenção da sua vida, tomar uma decisão a respeito de um procedimento estético como a reconstrução mamária pode parecer irrelevante. Quando esta opção lhe é oferecida, a decisão a respeito da mesma pode ocorrer por impulso ou até mesmo pela plena confiança depositada nas decisões médicas.

Considerando esses aspectos, destaca-se que apesar de a influência do médico ter representado importante fator na condução da mulher à sua decisão e esta influência ter sido considerada benéfica pela maioria das mulheres, torna-se imprescindível que o médico proporcione à mulher o conhecimento adequado a respeito dos diferentes tipos de abordagem cirúrgica para realização da reconstrução mamária, alertando-a sobre as complicações e benefícios relacionados a cada cirurgia, a fim de que, apropriada de tais informações, ela possa assumir uma posição ativa no processo decisório.

Nesse contexto em que a figura do médico é compreendida como a de alguém que quer ajudar, buscando “diminuir os problemas”, Duarte e Andrade (2003) afirmam que para a mulher, o médico consiste no principal referencial, tanto no que se refere aos aspectos objetivos relacionados ao tratamento da doença como, por exemplo, a escolha do procedimento cirúrgico, quimioterapia, radioterapia, quanto aos aspectos subjetivos, como expectativas, insegurança, medos, angústias e depressão.

Essa condição pode ser observada na fala de Nair que, apesar de reconhecer que não recebeu informações suficientes para que pudesse participar do processo de decisão sobre sua cirurgia, acredita que o fato de ter sido privada dessas informações foi algo positivo, pois admite que não teria condições de decidir pela reconstrução da mama, caso a mesma não lhe tivesse sido imposta pelo médico:

"O médico, na hora que ele falou que eu ia fazer a cirurgia, ele já falou que ia fazer a reconstrução. Então foi meio imposto pra mim, ele não perguntou se eu queria fazer a reconstrução ou não e eu fiquei surpresa, mas ao mesmo tempo eu 
achei bom... olha, não foi explicado muita coisa não e a gente sendo leiga no assunto, não tinha nem pergunta pra fazer, sabe? Então eu não fui bem esclarecida sobre o assunto, mas achei que foi bom tudo como aconteceu... a gente fica assustada com o que foi falado: você precisa fazer a cirurgia. Aí você não entende, não sabe aquele leque de coisas que podem acontecer ou não, então você não sabe nem fazer pergunta pro médico. Depois que você vai embora, você fala: poxa! Eu precisava saber isso, aquilo, mas é depois que você vai ficar pensando no assunto, mas na hora que você fica sabendo do diagnóstico e tudo, o que o médico falar pra você, você faz." (Nair)

Essa falta de conhecimento acerca da cirurgia foi também observada em estudo realizado com 1.844 mulheres submetidas à mastectomia, no qual a maioria relatou ter discutido com o médico sobre a reconstrução da mama, no entanto, observaram-se pouco conhecimento sobre o procedimento no que disse respeito à necessidade de múltiplas cirurgias, o impacto da reconstrução na detecção de recorrência da doença e alterações sensoriais na mama (MORROW et al., 2005).

O desconhecimento manifestado pelas mulheres do estudo de Morrow et al. (2005), assim como pelas mulheres do presente estudo, pode estar relacionado à ausência de informações adequadas a respeito da cirurgia. Observa-se que, de maneira geral, as mulheres não são incorporadas ao processo decisório, e quando o são, não estão devidamente informadas para que sua decisão possa ser completamente satisfatória, o que pode levar a uma possível frustração futura com relação às consequências negativas advindas da cirurgia.

De acordo com Chen et al. (2008), é importante haver a discussão entre médico e paciente sobre as possibilidades de reconstrução mamária após cirurgia para câncer de mama. Essa discussão sobre o procedimento possibilita à mulher mastectomizada a obtenção de informações suficientes sobre os benefícios e riscos do mesmo, o que pode ajudá-la a compreender sua situação e fazer melhor suas escolhas.

A atitude do profissional de convencer a mulher a realizar a reconstrução mamária pode refletir a sua capacidade de pensar nas consequências negativas do câncer sobre a vida da mulher, considerando a reconstrução da mama como uma forma de amenizar o sofrimento advindo do tratamento cirúrgico para a retirada do tumor.

Os argumentos utilizados pelos profissionais, ao estimular a realização da cirurgia reconstrutora às mulheres deste estudo, foram frequentemente relacionados à idade, no caso das mulheres mais jovens, e à possibilidade que a reconstrução oferece de promover bemestar físico e emocional às mulheres que passam por uma cirurgia mutiladora:

"Foi na hora o médico falou que queria fazer já a reconstrução na hora pra eu não sair sem a mama, porque o Dr. X (médico da usuária) disse assim: na hora 
que você já fica sabendo do câncer a pessoa já fica em depressão, então imagina sair sem as mamas. Então ele falou pra mim: eu não deixo nenhuma paciente minha sair sem as mamas daqui. Eu, como fui de gaiata, não sabia de nada, aceitei, fiquei toda feliz." (Gisele)

"Aí depois ele (médico) falou: vamos reconstruir porque você é muito nova, depois a gente reconstrói pra você...” (Joana)

Ressalta-se que a maioria das mulheres deste estudo recebeu o diagnóstico de câncer de mama antes dos 45 anos, o que pode explicar, em parte, a frequência de relatos que indicam a insistência do médico em realizar a cirurgia reconstrutora imediata, corroborando outros estudos que mostram que mulheres jovens e com parceiro recebem maior incentivo à realização da reconstrução mamária por parte dos médicos e que as informações oferecidas podem variar em função das características clínicas da mulher (CHEN et al. 2008; ALDERMAN et al., 2008; MORROW et al., 2005).

É provável que essa atitude dos profissionais esteja relacionada ao fato de muitos acreditarem que a mama, para a mulher jovem, possui maior função sexual e estética do que para mulheres com idade mais avançada, para as quais a mama já desempenhou, ao longo da vida, seus papéis essenciais dentro do contexto social e sexual. Nesse sentido, em seu estudo, Aureliano (2007) observou que as mulheres com idade acima de 50 anos utilizavam, como justificativa para a não realização da cirurgia reconstrutora, os aspectos “utilitários” da mama, tais como a amamentação e/ou sedução, já que para essas senhoras, não fazia sentido se submeter ao risco de uma cirurgia tão grande se elas não iriam mais amamentar ou expor seus corpos. Elas acreditavam que se o aspecto “funcional” daquele órgão não existia mais, não havia porque reconstruí-lo.

\subsubsection{A experiência pós-reconstrução mamária}

\section{Os benefícios da reconstrução mamária}

\section{A recuperação da autoimagem}

As cicatrizes causadas pela mastectomia ou pela utilização de enxertos com tecido obtido de outras partes do corpo para refazer a mama (que pode também não oferecer o formato e tamanho que as mulheres almejam), e mesmo a parte enxertada, podem incomodar 
a mulher. Inicialmente, ela pode não considerar esse tecido implantado como uma mama, mas após algum tempo, percebe-se completa, com uma nova mama, que aos poucos é incorporada à sua autoimagem:

“Eu falo às vezes como que é? quando o enxerto vai... (aperta o antebraço e faz uma prega para tentar demonstrar) como que fala? Quando o enxerto vai já pegando o corpo mesmo. Entendeu? Eu falo assim que o peito já fez o meu enxerto, já faz parte do corpo ali mesmo... agora mesmo que esteja costurado em volta as marquinhas, mas você se sente bem melhor, parece que é normal, você sente seu corpo normal.” (Anita)

Recuperar a mama perdida, em decorrência do câncer, devolve à mulher sua autoestima e apesar de, em alguns casos, a mama já não ter mais a função de amamentação, ela é importante para a construção da autoimagem. A sensação de “estar inteira” novamente ajuda a aceitar sua nova imagem e a superar a mutilação causada pela cirurgia.

É interessante observar como algumas mulheres conseguiram definir um parâmetro para aceitar essa nova mama, comparando-a não com a mama que não fora operada, mas com a que fora extirpada com a cirurgia, conseguindo, portanto, se satisfazer com o resultado da reconstrução que lhes trouxe de volta a vontade de se olharem no espelho e se sentirem femininas novamente.

\footnotetext{
"Eu sou muito vaidosa assim, gosto de me arrumar, mas diante da doença, nossa! eu acho que eu tô linda, tá ótimo! Pra mim não precisa mexer em nada. Gostaria que todas as pessoas que tivessem, tivesse a chance também de reconstruir. Acho que ajuda muito a autoestima. Acho muito importante... eu tô satisfeita. Porque a função da minha mama era ter filhos, amamentar. Hoje, com a minha idade, eu acho que tá tudo bom...” (Fátima)

“...é uma forma de você recuperar o teu lado mulher. Uma forma de você se olhar no espelho e se aceitar mais, porque mulher nenhuma se sente feliz sendo mutilada, nenhuma! Acho muito difícil uma mulher se olhar no espelho e falar que se acha bonita mutilada. Não. Eu acho que você tem que procurar o seu melhor... é uma forma da mulher recuperar sua autoestima...” (Luisa)
}

Como observado neste estudo, para muitas mulheres, a reconstrução da mama reduz o trauma da mutilação, proporciona o resgate da autoestima e autoimagem, restaura sentimentos de atratividade e feminilidade e aumenta a vontade de realizar cuidados estéticos. Nesse sentido, Teixeira (2008) acrescenta que a liberdade de poder usar qualquer tipo de roupa traz à mulher maior segurança e bem-estar e está relacionada à satisfação em ter de volta sua forma feminina.

A recuperação da integridade corporal influencia na satisfação geral das mulheres, e mesmo que não possam recuperar a mama perdida ou apagar as cicatrizes causadas pelas 
cirurgias, a obtenção de volume, forma e textura similares à mama natural contribui de maneira relevante para a recuperação da autoestima (SANHES et al., 2006). O sentimento de perda e mutilação causado pela mastectomia é amenizado, e as mulheres sentem maior segurança e liberdade para frequentar ambientes sociais:

“...eu acho que a reconstrução, ela, emocionalmente, ela ajuda a gente não se sentir mutilada. Eu acho que essa sensação de volume que a gente tem, eu acho que a gente não sente tanto a perda da mama... eu acho que emocionalmente é muito importante pra mulher a reconstrução mesmo que ela fique diferente e tal, mas essa sensação de volume que a gente continua tendo, porque você veste as roupas, você sente que você tem mama, sente que você tem mama." (Marta)

“A reconstrução facilita porque já tá como se fosse sua mama mesmo e não chama atenção e não causa nenhum constrangimento... se puser um biquíni, não vai prejudicar em nada na aparência... é confortável, dá liberdade, tanto pra usar uma roupa, quanto pra se trocar na frente de uma outra pessoa." (Carla)

As mulheres deixam claro que não é preciso ter uma mama exatamente como a que tinham antes da cirurgia e destacam que o volume oferecido pela prótese ou retalho proporciona tranquilidade para que elas possam usar vários tipos de roupas, inclusive as que expõem parte dessa nova mama, sem precisar se preocupar se a prótese se deslocou ou poderá aparecer, ou até mesmo cair, preocupação esta claramente observada nos relatos das mulheres que utilizaram a prótese mamária externa, antes de se submeterem à cirurgia reconstrutora:

“Nossa! essa aqui (mama reconstruída) é muito melhor! Aquela (prótese externa) não fica bom. Aquela externa não pára direito, não fica certinho. Essa daqui (mama recontruída) fica perfeito, se eu pôr uma roupa, se eu pôr um biquíni, fica perfeito... biquíni eu ponho sim, ponho pequenininho e fica bom..." (Joana)

“...me ajudou bem, a minha estética, mais a estética pra vestir uma roupa, pra, sabe assim, ficava muito desproporcional, se botava uma roupa ficava a mama grande, muitas vezes ficava, sei lá, era muito desconfortável, não gostava não dessas próteses que a gente põe... Então graças a Deus é melhor do que você usar uma coisa artificial. Pra mim foi ótimo!... se eu fosse numa piscina, um clube, alguma coisa, eu botava aquelas coisas (próteses mamárias externas) dentro do maiô, porque eu tinha, peguei no SUS as próteses, mas eu falei assim, graças a Deus a gente usa as coisas, não precisa tá mais... graças a Deus eu tô bem, e faria de novo se fosse preciso." (Eva)

A mama é um órgão que exerce papel importante na sexualidade da mulher. A ausência desse órgão pode afetar o relacionamento com seu parceiro pelo fato de a mulher não sentir mais que possui a imagem que corresponde aos parâmetros socialmente impostos em relação ao corpo feminino. No entanto, a reconstrução mamária oferece a ela a possibilidade de restituir essa imagem perdida, fazendo com que ela se sinta mais satisfeita consigo mesma. 
Para muitas mulheres, exercer a sexualidade de forma plena e sentir-se atraente é mais importante que sentir-se à vontade para usar decotes, que o desejo sexual do parceiro e até mesmo mais importante que sua própria aparência (HUGUET et al., 2009). Ter a mama de volta, mesmo que incompleta ou com cicatrizes, faz com que algumas mulheres se sintam seguras e estimuladas a manter ou iniciar um relacionamento afetivo e sexual com um parceiro, principalmente quando se trata de mulheres jovens e com vida sexual ativa:

“...me trouxe grandes benefícios a reconstrução, me ajudou a ter uma vida melhor, me dá prazer de viver, prazer de namorar, prazer de um monte de coisa... então eu não vou deixar de ter minha vida sexual, de ter meu parceiro, de namorar por causa da minha mama." (Bruna)

“...você vai ter um encontro com uma pessoa e você não tem a mama né. Agora eu acho que isso faz muito a cabeça da pessoa." (Gisele)

A segurança em retomar as atividades sexuais com o parceiro ou iniciar um novo relacionamento afetivo, após a realização da cirurgia reconstrutora, sugere que é possível a recuperação da integridade física e psíquica, após a retirada da mama.

\section{A superação da doença}

O medo de se sentir amputadas quando se viram diante do diagnóstico de câncer de mama foi um dos sentimentos mais frequentes relatados pelas mulheres. Sair da cirurgia com uma mama nova representou um estímulo para que elas se recuperassem mais rapidamente e as ajudou a enfrentar melhor o tratamento e superar o trauma causado pela doença.

“...fiquei bastante feliz em saber que eu ia melhorar, que eu ia ficar bem, porque eu via a minha mama. Ela foi muito importante pra mim, a reconstrução. Sabe, me ajudou até a melhorar. Em poucos dias eu tava na rua, já tava andando, já tava... sabe, levando a minha vida normal, você entendeu?...é tudo de bom na minha vida." (Bruna)

Os depoimentos das mulheres deste estudo mostram que elas sentem que olhar para o “vazio" deixado pela mastectomia traz à tona a lembrança da doença e do sofrimento causado por ela. A reconstrução mamária, ao substituir esse “vazio”, faz com que ela consiga superar os sentimentos negativos que permeiam a doença, já que evita que ela recorde a todo o momento que passou por um câncer.

Nesse sentido, a reconstrução é vista como a coroação de um tratamento bemsucedido, podendo-se perceber, em algumas falas, a associação da reconstrução mamária à 
resolução do câncer de mama, a uma forma de ter se livrado definitivamente da doença. Para essas mulheres, com a retirada da mama, retirou-se também o problema, no caso, o câncer. Sendo assim, ao reconstruírem a mama, elas adquiriram mais tranquilidade e confiança para retornar à sua vida normal, o que fez com que elas conseguissem dar à nova mama o significado de “ponto final” à sua doença e tivessem suas vidas também reconstruídas:

"Parece que foi uma coisa mais definitiva. Então, agora que fez a reconstrução, tirou tudo, então agora você tá bem. Foi assim que eu pensei porque quando eu fiz a segunda cirurgia eu pensei: já fiz a primeira, já fiz a segunda, será que eu vou ter câncer de novo nessa mama? Aí tive né. Aí fez a reconstrução, mas eu fiquei tranquila, eu achei que agora tá tudo bem. Foi bom, foi um alívio, fiquei confiante de que eu estaria bem... foi uma maneira de me fazer sentir melhor do que se eu não tivesse feito. Deu assim como se fosse um limite pras coisas, tirou o que era necessário, era necessário fazer isso, então vamos fazer uma reconstrução pra finalizar. Então foi uma finalização do meu problema de câncer na mama." (Nair)

“...eu acho que a reconstrução foi a melhor coisa. Ela supriu toda a doença." (Fátima)

"Eu acho, você tá ali com as suas duas mamas, eu acho que é muito melhor do que você olhar e ver aquele vazio porque toda hora que você olhar e ver, sabe? Dá aquela... você vai tá lembrando que você tá sem a mama porque você teve um câncer. Agora se você cobre aquele espaço ali, é uma coisa superada, eu acho que é a coroação de um tratamento mesmo, sabe? É aquilo que você olha e fala: não! Eu tratei, mas tá lá, ainda tô com a minha mama.” (Marta)

O fato de as mulheres terem demonstrado total confiança no médico que as estava operando foi um dos fatores que contribuiu sobremaneira para essa certeza de cura, visto que elas acreditaram que a cirurgia reconstrutora somente foi realizada porque não havia nenhuma contraindicação, ou seja, não havia mais a chance de retorno da doença. Nesse contexto, estudo com mulheres mastectomizadas mostrou que elas acreditam que o progresso tecnológico e o saber médico são a alternativa para elas realizarem a reconstrução da mama, o que para elas representa a possibilidade de alcançar a cura, voltar ao normal e formar outra identidade como mulher (FERNANDES; MAMEDE, 2003).

\section{Os problemas ocasionados pela cirurgia}

\section{A insatisfação com o aspecto da nova mama}

A transformação do corpo é algo que será constantemente negociado para as mulheres que realizam a reconstrução mamária, pois se trata de um corpo modificado e reconstruído. 
Apesar de propor a recomposição dos corpos mutilados, a reconstrução autóloga (realizada com tecidos obtidos do abdômen ou do músculo dorsal), em muitos casos, pode ser percebida e sentida como mais uma mutilação (AURELIANO, 2009).

Quando se retira uma parte do corpo, como por exemplo, um retalho da região dorsal ou abdominal para reconstruir a mama, esses retalhos, por estarem em regiões onde a exposição ao sol costuma ser maior e a textura da pele diferente da textura da mama, podem não formar uma mama que se assemelhe à original. Tais cirurgias também costumam deixar cicatrizes ao redor do implante, o que, muitas vezes, pode fazer com que a mulher não aceite esse retalho como uma mama, e sim como um "pedaço de carne”, algo paliativo, que não devolve a ela a sensação de feminilidade perdida com a cirurgia para retirada do tumor.

“A mama, a gente vê que não tem nada a ver com a mama, não parece uma mama normal mesmo. É uma carne aí ó... um pedaço de carne. É bem, eu acho assim bem diferente a cor, até a tonalidade...” (Eva)

“Ah, provoca tristeza, sabe? Isso provoca tristeza na gente, sabe? Te deixa assim, dá impressão que te deixa menos mulher, sabe? Porque com a cirurgia parece que você sai toda picada entendeu? Então eu acho que... te deixa menos mulher sim...eu queria ter meu seio normal, sabe?...” (Bruna)

No caso das mulheres nas quais foram utilizadas próteses de silicone para reconstruir a mama, a sensação referida é a de estranhamento. Como a cirurgia para retirada do tumor causa cicatrizes e perda de tecidos adjacentes, a prótese, muitas vezes, quando implantada nesse espaço, não proporciona uma aparência simétrica à mama e faz com que esta tenha um aspecto muito diferente da mama contralateral. Nesse sentido, Azevedo e Lopes (2005) observaram, em seu estudo, a dificuldade de aceitação, por parte das mulheres que se submeteram à reconstrução com prótese, das alterações que a cirurgia pode ocasionar, fazendo com que as mesmas não adquirissem a imagem corporal esperada. No presente estudo, pôde-se observar resultado semelhante, o qual pode ser exemplificado nas falas a seguir:

"Porque muitas vezes você põe uma blusa e a gente vê que tem um vão aqui. Dependendo do decote você vê que tem... Olha, no começo eu sempre brincava, eu falava: essa é de silicone, essa é de silicone. Agora pra mim é tudo normal... Ah, eu fui me conformando aos pouquinhos." (Denise)

“...um ponto negativo que eu acho assim, é uma prótese, não é uma mama, então é uma coisa que não é natural, é uma coisa artificial... a gente sempre espera mais... Então, queira ou não queira, no meu íntimo, eu esperava que chegasse o mais próximo possível da mama mas não chega, é diferente.” (Luisa) 
A insatisfação da mulher com relação à mama reconstruída pode estar relacionada ao comprometimento nos resultados da cirurgia como, por exemplo, presença de cicatrizes visíveis, falta de naturalidade na aparência e alterações na sensibilidade e é possível que os problemas com a imagem corporal permaneçam por um longo período após a cirurgia, havendo a persistência dos sentimentos de diminuição da feminilidade e a falta de desejo sexual (AZEVEDO; LOPES, 2005; HEIJER; SEYNAEVE; TIMMAN et al., 2011).

Esses sentimentos podem ser exemplificados pela fala de Ivone que percebeu a mudança na sua relação com o companheiro. Ivone “deixou sua mama de lado” por não satisfazer às suas expectativas, principalmente nos momentos de privacidade entre ela e seu companheiro, nos quais ela não permitia que a mama fosse tocada ou vista. Como é difícil para ela se aceitar com essa mama imperfeita, também é difícil acreditar que ele a aceitaria, por isso ela faz o possível para escondê-la:

“...não, nunca falou (companheiro), nunca tocou (na mama)... não deixo (tocar na mama), nem ver. Se bem que eu ando dentro de casa, tudo. Mas eu não ando de peito aberto, porque eles não são iguais, então eu disfarço, tomo banho, ando da cozinha pro quarto, do quarto pro banheiro, mas sempre disfarçando, até pra ele (companheiro)... Tenho vergonha... eu mostro a normal, e essa daqui, como ela tem aquele fundinho, eu mostro só de lado." (Ivone)

A retomada da vida sexual pode levar algum tempo, já que as mulheres necessitam voltar a se olhar sem medo e gostar do que estão vendo e se tocar sem se sentirem diferentes (DECAT, 2006).

Há casos, no entanto, em que a deformidade da mama não afeta o relacionamento sexual, mas sim, o convívio em sociedade. A mulher, muitas vezes, irá se confrontar com os aspectos culturais referentes à construção da identidade feminina, sendo estes, certamente envolvidos na relação com a doença que possui uma simbologia e um significado cultural muito forte (SILVA, 2008).

Como estratégia para não se sentirem diferentes diante da sociedade, as mulheres deste estudo usaram de artifícios para disfarçar as imperfeições advindas da cirurgia, como irregularidades, diferença de tamanho e cicatrizes, o que evitou que outras pessoas as olhassem com estranheza ou perguntassem algo relacionado à sua doença.

O fato de as mulheres buscarem formas de esconder a mama operada evidencia sua indisposição em falar sobre o câncer. Quando escondem essas imperfeições com roupas e acessórios, conseguem não chamar a atenção das outras pessoas, evitando assim que surja algum assunto sobre a doença. 
"Eu falei: a gente tem que usar de artifícios pras pessoas não perguntarem nada pra gente... Eu falei: você sempre põe um colar, uma gargantilha, alguma coisa que vai chamar atenção pra pessoa e não atenção pra cicatriz.” (Denise)

“...aí quando eu vejo que tá muito decotado eu procuro levantar, ou prender mais com um broche, alguma coisa pra tampar. É estranho, eu evito, não por mim. Eu acho que as pessoas ficam olhando ali." (Eva)

Considerando-se a insatisfação gerada pelo aspecto da cirurgia e as mudanças que ela pode acarretar à vida da mulher, ressalta-se a importância de que as informações sobre a realização da reconstrução mamária se iniciem no momento do diagnóstico, para que a mulher tenha o tempo necessário para elaborar a perda da mama e possa tomar uma decisão sobre a necessidade de uma cirurgia reconstrutora e o tipo de cirurgia mais adequado, garantindo, assim, que o resultado possa ser satisfatório ao invés de gerar frustrações ainda maiores.

\section{O medo de perder a mama novamente}

As cirurgias para reconstrução utilizam enxertos com tecidos obtidos de outras regiões do corpo ou próteses de silicone para formar o montículo mamário. Esses tipos de cirurgias oferecem os mesmos riscos das demais cirurgias desse porte, como, por exemplo, rejeição do tecido pelo corpo, necrose e infecção. Algumas vezes, quando não é possível controlar esses problemas, pode haver a necessidade de remoção do retalho ou prótese.

A mulher passa por momentos de intenso sofrimento durante o tratamento, dentre eles, o medo da morte e da perda da mama. Nesse contexto, a reconstrução mamária surge como uma alternativa para que ela possa restabelecer sua autoimagem e superar o medo, visto que a cirurgia tem o objetivo de minimizar as consequências negativas causadas pela doença e pelo tratamento.

No entanto a ocorrência de problemas relacionados à cirurgia, como rejeição da prótese ou enxerto, e até mesmo a preocupação a respeito da possibilidade de ocorrência desses problemas trazem à tona o sentimento de medo manifestado no início do tratamento, e a mulher encara a possibilidade de perda dessa mama reconstruída como uma ameaça à sua integridade física e psíquica. Sua preocupação passa a ser relacionada ao aspecto da mama, caso haja sua perda, e à possibilidade de não haver mais alternativas para reconstruir essa mama novamente.

“...ele (médico) me falou que eu tinha que ter todo o cuidado pra não... a mão que eu tivesse (coloca a mão na barriga) jamais eu levasse a mão na mama porque senão passava pra mama a infecção, aí eu ia perder tudo... eu tinha medo mesmo, 
tive medo de aquilo apodrecer tudo ali e eu perder toda a mama. Eu tinha medo não era nem de perder a mama, era de ficar o buraco, onde eu ia arrumar tecido?" (Eva)

“...eu fiquei com medo de perder tudo. A gente fala ai meu Deus! E agora se eu perder tudo isso, se essa pele não ficar? Como é que vai ficar isso?... A gente tem medo de infecção, tem medo de febre, fica meio antenada nas coisas." (Karen)

As intercorrências não só colocam a mulher de frente com a possibilidade de um novo enfrentamento do tratamento e da reabilitação, como também trazem à tona a extrema vulnerabilidade a que ela está exposta (SILVA; SANTOS, 2008).

O medo de ficar com a mama “defeituosa”, por exemplo, reflete-se na decisão pela finalização da cirurgia reconstrutora. E nesse sentido, alguns outros motivos como o avanço da idade e o benefício que a reconstrução trouxe diante do câncer fazem com que as mulheres acreditem que a cirurgia para finalização seria meramente estética e elas estariam se submetendo a um "risco desnecessário" de perder a mama novamente, caso houvesse complicações.

Há de se destacar, também, que problemas relacionados à imagem corporal após a cirurgia também podem resultar em falta de interesse por uma nova intervenção, como por exemplo, a reconstrução do complexo aréolo-mamilar (HEIJER; SEYNAEVE; TIMMAN et al., 2011).

Assim, as mulheres, ao se depararem com o diagnóstico do câncer, enfrentam o medo da morte. Depois, com a cirurgia, perdem a mama, um pedaço de seu corpo. A reconstrução dessa mama, apesar de refazer, de melhorar a autoimagem e a autoestima, não fica perfeita, e então, quando elas se veem diante da possibilidade de complicações, deparam-se novamente com o sentimento de medo e evitam finalizar as etapas da reconstrução.

“...tenho medo de tá mexendo na cirurgia e tal, de dar problema em qualquer coisa. Às vezes pode dar problema e ter que tirar o silicone fica pior... Não vou mexer, vou ficar quieta...” (Joana)

“Eu ainda tenho medo de mexer... Eu fiz, mas não senti... que já foi posto o silicone. Agora, já pensou, por uma vaidade, pra ficar melhor eu ficar sem a mama por causa de rejeição? Acho que não é importante agora." (Fátima)

É possível observar que a mama reconstruída é, aos poucos, aceita como uma mama verdadeira pela mulher e, mais que isso, representa a superação da doença, a "volta por cima" depois de todo o sofrimento. Diante da superação e do conforto atribuídos à reconstrução, melhorar a estética se torna algo supérfluo e até mesmo arriscado, já que pode provocar uma 
nova perda, ainda mais dolorosa, pois a mulher acredita que o resultado da perda desta nova mama pode ser ainda pior que a mastectomia.

Esse pensamento torna-se explícito nas falas das mulheres que realizaram a reconstrução imediata, como no caso de Fátima, já que não precisaram passar por uma segunda intervenção cirúrgica para a reconstrução, o que é visto por elas como um ganho, considerando-se a necessidade da cirurgia para retirada da mama e o benefício de poder reconstruí-la no mesmo momento. Nesses casos, submeter-se a uma nova cirurgia para a melhoria estética pode representar uma ameaça desnecessária.

\section{A perda da sensibilidade da mama}

A perda da sensibilidade da mama mostrou-se uma consequência comum a todas as mulheres deste estudo. Por meio dos relatos, pôde-se observar grande dificuldade por parte dessas mulheres em aceitar que o tecido implantado assemelha-se a uma mama, já que este não oferece de início, e em alguns casos, de forma permanente, a mesma sensibilidade das demais regiões do corpo. A pele fria e a presença de cicatrizes, aliadas à ausência da sensibilidade, provocam em algumas mulheres a sensação de que aquele enxerto se trata de uma "pele morta” que não faz parte do seu corpo:

“...é porque você perde a sensibilidade. Então mesmo você tendo peito você não tem aquela sensibilidade normal que você tinha. Então só isso que a gente sente... porque fica como se fosse uma pele morta mesmo..." (Anita)

“...eu ainda tenho, por exemplo, ela é fria, a sensibilidade é muito diferente e como puxou a musculatura, aqui (mostra a região da axila) não pegou e fica sem, uma sensação esquisita que afunda mais, que não tem aquela capa, uma sensação esquisita... é como você sentir a perda, a temperatura é diferente, então isso dá uma sensação de que não é parte do seu corpo, porque é frio.” (Hilda)

Gahm et al. (2007) mostram, em seu estudo, que a maioria das mulheres que realizaram a reconstrução mamária, quando questionadas sobre o retorno da sensibilidade na mama reconstruída, referiu sentir desconforto quando recebeu estímulos na mesma. A maioria das mulheres informou que percebiam a mama reconstruída como real, mas uma pequena minoria delas disse que conseguia experimentar sensações sexuais nessa mama.

Esses resultados corroboram os do presente estudo, em que se observou que as mulheres têm dificuldade em exercer a sexualidade quando a sensibilidade da mama é comprometida. Uma parte do corpo que, antes, ao ser tocada promovia a sensação de prazer, 
passa a causar o sentimento de incômodo, pois pode fazer com que ela a associe à doença cada vez que é tocada:

“...porque isso faz parte, faz parte da sexualidade da gente. A mama, ela faz parte de um monte de coisa e a gente tem muita sensibilidade na mama. Mesma coisa, na sexualidade ela tem bastante sensibilidade. Quando me toca eu sinto bastante e agora tá meio comprometido.” (Bruna)

"Não é a mesma coisa que você passar a mão na tua pele e passar a mão na mama com prótese. Não é a mesma coisa. Você perde um pouco da sensibilidade... é uma coisa meio incômoda. Particularmente, eu não gosto muito de ser tocada não porque por mais que você tente trabalhar tua cabeça, é uma coisa que mexe com você. Não é uma coisa natural da tua vida, que você, involuntariamente você desencana, não!” (Luisa)

Algumas mulheres, ao retomarem sua vida sexual após a cirurgia, sentem muita dificuldade devido ao medo da rejeição por parte do companheiro. Mesmo com a mama reconstruída, não permitem que a mama seja tocada devido ao incômodo provocado pela ausência da sensibilidade (DUARTE; ANDRADE, 2003).

É possível, portanto, observar que apesar de a mulher recuperar, em algumas vezes, a função estética da mama, a sensibilidade afetada é responsável pela presença de sensações negativas. Sendo assim, elas buscam alternativas para exercer a sexualidade com seus companheiros como, por exemplo, por meio do toque em outras partes erógenas do corpo.

Nesse sentido, estudo de Bertolo e Pauli (2008) observou que as mulheres, ao lidarem com a mutilação, passavam a conviver e a se relacionar com um novo referencial de corpo, no qual o prazer e a libido tornavam-se enfocados no corpo todo.

Essa iniciativa de buscar outras áreas erógenas apareceu entre as mulheres do presente estudo, refletindo a capacidade de adaptação à sua nova realidade, e a ajuda do companheiro nesse momento foi de grande importância para a descoberta e aceitação do seu corpo.

“Ah, a gente tem sensibilidade em outros lugares (risos).” (Anita)

"Tem outros meios né (risos)... ah, eu acho assim, tem outras partes mais sensíveis né? como que eu vou te falar?” (Gisele)

"Eu tenho o outro (seio) e não ligo não. Meu marido também não ligou. Meu marido é muito compreensivo, ele não liga tanto assim não... tanto ele (marido) passa a mão na outra como nessa também, como se fosse normal. Ele fica brincando (risos) ele passa na outra (mama), mas não esqueceu dessa, apesar de eu não sentir, ele passa a mão também brincando com essa, ele não passa a mão só na outra. Então pra mim é normal.” (Joana) 
As cirurgias para o tratamento do câncer provocam mutilações na imagem corporal da mulher, e suas consequências deixam marcas físicas, emocionais, sentimentos de estranheza, rejeição, vergonha e medo. Sendo assim, o companheiro tem papel fundamental na fase de enfrentamento da doença. Os sentimentos de amizade, respeito, compreensão e carinho para com suas parceiras representam o apoio necessário para que elas consigam contornar os obstáculos deixados pela cirurgia (GASPARELO et al., 2010).

\section{$\underline{\text { Redes de apoio à mulher }}$}

O câncer é uma doença permeada por sentimentos negativos e acarreta uma série de comprometimentos físicos, psíquicos e sociais à mulher, o que pode fazer com que ela se sinta diferente das outras mulheres e excluída de seu meio social. Nesse sentido, as redes de apoio às mulheres com câncer se mostram presentes em todas as fases do adoecer, desde o diagnóstico até a reabilitação. A família, os amigos e os grupos de reabilitação são as fontes de suporte mais frequentes entre essas mulheres, e sua participação é de fundamental importância para a reinserção das mesmas na sociedade.

\section{O papel da família e dos amigos}

A doença, além de afetar a mulher, afeta também as pessoas com as quais ela convive, principalmente a família, o que leva a desadaptações/alterações no cotidiano de todo o grupo familiar. Nesse contexto, a família é vista pela mulher como uma fonte de apoio, ajuda e segurança, bem como cuidadora, por promover o acolhimento de seus integrantes (FEIJÓ et al., 2009).

Nos relatos das participantes deste estudo, observa-se esse acolhimento por parte da família, a qual teve importante participação no processo de escolha pela reconstrução mamária, oferecendo apoio e incentivando a mulher a realizá-la. Pôde-se observar sua preocupação em fazer com que a mulher não se sentisse mutilada, já que tanto o companheiro, como as demais pessoas da família ofereceram apoio financeiro para a obtenção da prótese de silicone e até mesmo da prótese mamária externa, quando a mulher precisou esperar pela cirurgia.

“...meu marido comprou pra mim (prótese mamária externa), pagou uma nota em silicone, sutiã e tudo. Eu falei: não vai comprar não, num instantinho vai reconstruir. Ele (marido) falou: não, vamos comprar sim." (Joana) 
"Ele (médico) deu a opção. O meu marido, na hora que ele falou, é... que já se podia fazer a reconstrução, falou: então vamos fazer!... o convênio não pagava, minha família me deu de presente, o presente de Natal foi, como eu falo, um peito turbinado."(Denise)

Esse incentivo à realização da reconstrução mamária pôde também ser observado entre os amigos que, quando na ausência da família ou até mesmo de forma complementar à mesma, estiveram ao lado das mulheres, atuando de forma a promover seu fortalecimento e bem-estar.

“...teve algumas amigas, vizinhas que falavam, ah, você devia fazer porque você é nova...” (Anita)

"Até meus amigos falavam: vai tirar? Eu falei pra eles (amigos) que depois ia reconstruir. Eles ficavam em cima de mim: vai reconstruir? Reconstrói! Eu tava com medo, falava com eles (amigos), eles falavam: vai dar tudo certo!” (Joana)

"Eu vim na segunda, só que ela (amiga) não pôde vir junto, aí começou a vir meu marido, aí já ficou difícil pra ela. Ela queria tá junto.” (Joana)

As pessoas próximas às mulheres têm fundamental importância na sua trajetória, visto que muitos sentimentos que surgem com relação ao câncer dependem da maneira como as mesmas serão vistas e recebidas pela família, amigos e profissionais da saúde (VIEIRA; LOPES; SHIMO, 2007).

Quando a mulher recebe alta e retorna à sua casa depois da cirurgia, há a necessidade da continuidade dos cuidados neste ambiente, pois a mesma ainda não é capaz de realizar tarefas simples relacionadas ao seu autocuidado, devido às limitações ocasionadas pela cirurgia. Dessa forma, observou-se o apoio por parte da família em relação à realização de cuidados depois da cirurgia, no que diz respeito à troca de drenos, banho, alimentação e também à preocupação com o bem-estar da mulher por meio de manifestações de carinho e cuidado. Esses cuidados foram oferecidos às mulheres tanto no pós-operatório da mastectomia como da cirurgia reconstrutora.

“...a minha cunhada que me dava banho, outras vezes era minha filha, e a minha filha que limpava os drenos pra mim, outras vezes era minha cunhada... eu tive apoio tanto psicológico como também, braçal.” (Gisele)

“...ela (mãe) ficou até meus pontos caírem parece, aí ela tinha que ir embora e meu marido ficou pra cuidar...” (Ivone)

"Eu tive muito apoio da família, muito carinho, muita atenção, muito cuidado e isso daí foi uma coisa que eu acho que também tem uma influência muito grande... eles tinham que cuidar muito de mim porque de uma certa forma, financeiramente, eu que gero todos os recursos maiores mesmo de dentro da família, sou eu." (Marta) 
Nota-se que os familiares se mostram diretamente envolvidos no processo de adoecimento por câncer, permanecendo com a mulher em todos os momentos da doença, desde o diagnóstico até os cuidados no domicílio, oferecendo apoio, cuidado e incentivo. Sendo assim, há a necessidade de os profissionais da saúde efetivarem a família como parceira e alvo no cuidado do paciente e incluí-la como sujeito de pesquisa, de forma que possam ser elaboradas intervenções num contexto sistêmico, valorizando todas as instâncias: físicas, emocionais, sociais, culturais, espirituais e éticas (INOCENTI; RODRIGUES; MIASSO, 2009).

\section{O apoio do REMA}

Muitas vezes, ao receber as informações sobre a cirurgia reconstrutora, durante a consulta médica, a mulher pode sentir-se insegura por não compreender todos os riscos e os benefícios inerentes à mesma. O fato de estar vivenciando uma situação de estresse, causada pelo impacto do diagnóstico, pode fazer com que as informações que o profissional oferece não sejam assimiladas por essa mulher. Participar de grupos homogêneos, como os direcionados a mulheres mastectomizadas, proporciona a oportunidade de troca de experiências, por se tratar de pessoas que vivenciam problemas similares. A ajuda, o esclarecimento e as informações oferecidas àquelas que ainda irão se submeter ao tratamento podem reduzir a expectativa e a tensão relacionadas ao desconhecimento (BACKES; KOERICH; ERDMANN, 2007). Essa busca por novas fontes de ajuda e informação pode ser observada nos depoimentos a seguir:

"Quando eu fui fazer a reconstrução, que eu ia operar, eu fui lá no Rema sem conhecer e eu falei, e eu pedi para alguém me mostrar. A Ivone (Sujeito deste estudo), ela tinha feito a reconstrução há onze anos, não sei, mais de dez e ela é muito expansiva, ela falava pra gente: faz onze anos que eu tô com meu silicone e eu tô garantida! E ela é miúda assim também e eu falava: teu silicone tá aí? Ela falava: tá, faz dez anos! Aí, aquilo ali pra mim foi tudo, eu não quis, eu não vi nada, ela não precisou me mostrar, então eu já saí dali com a segurança que eu ia pôr silicone e que eu ia ficar bem, então eu acho que isso é muito importante... Quando o médico conta pro paciente é uma coisa, agora o paciente ver uma outra pessoa que já teve a mesma coisa dá muita força. Eu acho que é muito importante, pelo menos pra mim foi muito importante. Eu acho que o REMA é um apoio muito bom." (Fátima)

“...Eu acho que é importante porque é uma ajuda mútua entre as pessoas que frequentam.” (Hilda) 
É importante destacar que a participação em grupos de apoio pode minimizar o sofrimento causado pelo câncer por possibilitar a vivência com outras mulheres que possam pela mesma experiência, proporcionando, assim, o reconhecimento de que poderá, juntamente com as demais, enfrentar barreiras e superar limites. Participar desses grupos faz com que a mulher não se sinta só, já que se trata de um ambiente no qual é possível trocar experiências e com isso redescobrir a vontade de viver (PINHEIRO et al., 2008).

Essa ajuda mútua fica evidente nos casos em que a mulher chega ao grupo com o sentimento de insegurança a respeito da sua recuperação. Aos poucos, com a ajuda dos profissionais e das demais integrantes do grupo, a mesma passa a perceber melhora no seu estado físico e sua reinserção no meio social, o que a torna forte e segura o suficiente para que ela seja também capaz de oferecer suporte às demais mulheres que compõem o grupo.

“...você chega aqui (REMA )...chega imobilizado, de repente você vai se soltando. Então você dá conselho pros outros. Alguma que você vê: tenho vontade de reconstruir. Eu falo: se for tua vontade, então reconstrói... desde a reconstrução, desde que eu entrei aqui, a gente aqui sempre aprende, sempre vê os outros, aqui é muito bom mesmo... É muito bom mesmo pra cabeça da gente, pra você aprender a conviver com a doença, com os problemas da cirurgia e outras coisas que também podem tá ajudando a gente.” (Joana)

Observa-se que o REMA é um ambiente no qual a mulher recebe informações, aprende novas formas de superação de suas limitações e desenvolve novas habilidades, o que faz com que ela se sinta mais segura para reassumir seu papel na sociedade. É possível inferir, portanto, que a forma como a mulher enfrentará os sentimentos relacionados ao diagnóstico de câncer e como irá se readaptar ao convívio social dependerá do suporte oferecido por seus familiares, amigos e profissionais da saúde (FEIJÓ et al. 2009). 


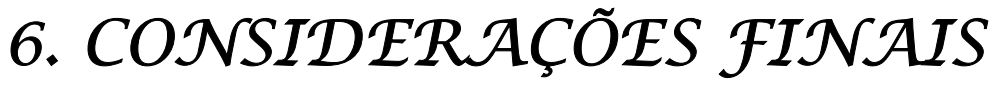


O câncer de mama se revelou como uma doença causadora de intenso sofrimento nas mulheres que, ao receberem o diagnóstico, manifestaram, de imediato, o desejo de ser curadas. A perda da mama, nesse momento em que o medo da morte predominou, foi colocada em segundo plano, e as mulheres aceitaram a mutilação, acreditando ser este o único caminho para a cura.

Diante do medo e da incerteza a respeito do resultado do tratamento, a maioria delas se sentiu confiante e segura com a figura do médico, o qual lhes trouxe a proposta da reconstrução mamária. Em alguns desses casos, foi ele quem escolheu o tipo de cirurgia e até mesmo o momento em que a mesma seria realizada, sendo possível observar que algumas mulheres não receberam informações suficientes para que participassem do processo decisório sobre sua cirurgia. Para elas, a equipe de saúde se mostrou centralizada na figura do médico, sendo que os outros profissionais não foram citados, com exceção de uma das mulheres que se lembrou da enfermeira atuando nas suas complicações pós-operatórias.

Apesar de o médico ter sido o principal responsável pela decisão por realizar a reconstrução mamária, em alguns casos as experiências negativas relacionadas ao uso da prótese mamária externa, ou até mesmo o medo do sofrimento causado pela mutilação da mama, fizeram com que as mulheres solicitassem a realização da cirurgia reconstrutora como uma forma de recuperar a feminilidade e a tranquilidade para retornar ao convívio social.

A respeito da experiência após a cirurgia reconstrutora, observou-se que a recuperação da mama devolveu a algumas mulheres sua autoestima e a sensação de estarem completas novamente; ajudou-as a recuperar sua autoimagem e a superar o trauma causado pela doença.

Olhar para a nova mama e sentir-se completa foi um fator determinante na diminuição da sensação de "vazio" causada pela mastectomia e trouxe tranquilidade para que elas conseguissem enfrentar o tratamento, sendo possível observar que, em alguns casos, as mulheres atribuíram à reconstrução mamária o significado de “ponto final” à sua doença.

A sensação de volume oferecida pela nova mama fez com que o sentimento de mutilação e de perda causado pela mastectomia fosse amenizado e proporcionasse às mulheres uma imagem que correspondesse aos parâmetros socialmente impostos em relação ao corpo feminino, devolvendo-lhes a segurança e a liberdade para frequentar ambientes sociais. Nesse sentido, apesar de a mama reconstruída estar incompleta ou possuir cicatrizes, essas mulheres sentiram-se também seguras para manterem ou iniciarem um relacionamento afetivo e sexual com um parceiro.

É importante destacar, no entanto, que a maneira como a mulher lida com as mudanças em seu corpo e a valorização referente à sua imagem antes da doença podem influenciar no 
modo como ela se vê depois da cirurgia. Dessa forma, algumas vezes a reconstrução da mama foi vista como mais uma mutilação.

Para as mulheres que apresentaram esse sentimento, as marcas deixadas pela mastectomia e pela cirurgia reconstrutora constituíram um estigma e as expunha aos olhares curiosos de outras pessoas. Com o intuito de não chamar atenção e evitar questionamentos a respeito da doença, algumas delas buscaram formas de esconder as imperfeições na nova mama com roupas e acessórios.

Todas as mulheres deste estudo relataram a perda da sensibilidade tátil da mama. Para muitas, a pele fria e a presença de cicatrizes aliadas à ausência da sensibilidade provocaram a sensação de que o enxerto não fazia parte do seu corpo, o que influenciou de forma negativa na sua sexualidade. Mesmo entre as mulheres que conseguiram recuperar a função estética da mama, a sensibilidade afetada gerou sensações negativas quando a mesma era tocada.

Nesse contexto, a descoberta e a exploração de outras partes erógenas do corpo foi uma das alternativas encontradas por elas para conseguirem exercer a sexualidade, e a ajuda do companheiro foi de fundamental importância nessa adaptação da mulher à sua nova realidade.

As mulheres também referiram o constante medo de perder novamente a mama, tanto no pós-operatório imediato à cirurgia reconstrutora no qual o medo esteve mais relacionado à rejeição da prótese ou retalho, quanto ao longo dos anos, estando a partir de então, relacionado à possibilidade de recidiva da doença. Esse temor refletiu-se também na decisão pela finalização da cirurgia reconstrutora, fazendo com que várias mulheres optassem por não realizá-la, por temerem complicações com uma cirurgia adicional.

Observou-se que as redes de apoio às mulheres com câncer se mostram importantes em todas as fases do adoecer, desde o diagnóstico até a reabilitação. A família, os amigos e o grupo de reabilitação foram as fontes de suporte mais frequentes, e sua participação mostrouse fundamental para a reinserção das mulheres na sociedade.

A participação do companheiro como cuidador nos períodos após a cirurgia e a sua compreensão e apoio nos momentos de vulnerabilidade da mulher, como por exemplo, durante as relações sexuais, foram de extrema importância para a reabilitação física e psíquica da mesma, proporcionando a ela a descoberta e a aceitação do seu corpo.

A família ofereceu apoio e suporte, principalmente no que diz respeito aos aspectos financeiros e aos cuidados após a cirurgia, e os amigos foram fonte de estímulo e apoio à realização da reconstrução. No grupo de reabilitação, elas encontraram um ambiente no qual 
receberam informações a respeito da doença e foram estimuladas a desenvolver novas habilidades, além de perceberem sua melhora física e psíquica.

Por compartilharem dos mesmos problemas, essas mulheres dividem histórias de insegurança, medo, superação e conseguem, ao longo do tempo, tornar-se também fonte de apoio às demais integrantes do grupo.

Considerando-se os resultados deste estudo, observam-se a importância e a necessidade de que os currículos de enfermagem envolvam, dentro do âmbito da saúde da mulher, as competências voltadas ao atendimento integral à paciente com câncer, inclusive no que diz respeito aos cuidados voltados a mulheres com reconstrução mamária.

Ainda no que diz respeito à formação de recursos humanos, é necessária educação permanente dos profissionais que atuam na área de saúde da mulher, a fim de que possam oferecer atendimento integral, considerando seu contexto sociocultural. Quando o profissional compreende os sentimentos que estão presentes na mulher que adoece por câncer e conhece os efeitos da reconstrução mamária na sua vida, torna-se, então, capaz de fornecer informações adequadas para que a mesma possa ser envolvida nas decisões a respeito de seu tratamento.

É necessário, portanto, que a mulher seja considerada como centro do processo de cuidar, levando-se em consideração seu conhecimento, sentimentos e expectativas. Para tanto, torna-se também necessário considerar a família como parceira e alvo do cuidado, já que esta constitui importante fonte de apoio em todas as fases do adoecimento e também compartilha os sentimentos negativos que permeiam a doença.

A reorganização do processo de trabalho de forma que o médico deixe de ocupar o lugar central, dando lugar a uma equipe interdisciplinar, pode proporcionar à mulher um espaço de acolhimento no qual ela sentirá segurança e receberá informações adequadas em todas as fases do adoecer.

Garantir a continuidade do acompanhamento das mulheres com câncer de mama implica o atendimento das mesmas por uma equipe interdisciplinar capaz de proporcionar acolhimento e recuperação física, psíquica e social. É, portanto, necessário que haja a formação de grupos de reabilitação espelhados no modelo apresentado neste estudo e a capacitação de profissionais que neles prestem atendimento, para que a mulher possa ser acompanhada logo no início do período pós-operatório, sendo-lhe garantido atendimento integral e humanizado. 
O dados obtidos neste estudo podem oferecer subsídios para a implementação de ações no âmbito do atendimento às mulheres com câncer de mama. Essas ações devem envolver paciente, família e profissionais de saúde.

Novos estudos científicos, a respeito da temática e para o aprimoramento dos profissionais de saúde, devem ser implementados, para que haja, assim, o fortalecimento das ações em saúde da mulher, especialmente entre aquelas com câncer de mama. 
7. REFER $\hat{E} \mathcal{N C I} \mathcal{A S}$ BIBLIOGRÁAICAS 
ABDO, C. Descobrimento sexual do Brasil. São Paulo: Summus, 2004.

ALDERMAN, A.K.; HAWLEY, S.T.; WALJEE, J. et al. Understanding the Impact of Breast Reconstruction on the Surgical Decision-Making Process for Breast Cancer. CANCER, v.112, n.3, feb. 2008.

ALMEIDA JUNIOR, G.L. Reconstrução mamária imediata com expansor de tecido: estudo retrospectivo. Revista Brasileira de Cirurgia Plástica, v.24, n.1, p.36-42, 2009.

ALVES, P.C.; SILVA, A.P.S.; SANTOS, M.C.L. et al. Conhecimento e expectativas de mulheres no pré-operatório da mastectomia. Revista da Escola de Enfermagem da USP, São Paulo, v.44, n.4,dez. 2010.

AMENDOLA, L. C. B.; VIEIRA, R. A contribuição dos genes BRCA na predisposição hereditária ao câncer de mama. Revista Brasileira de Cancerologia, v. 51, n.4, p. 325-30, 2005.

ARAÚJO, I.M.A. de; FERNANDES, A.F.C. O significado do diagnóstico do câncer de mama para a mulher. Escola Anna Nery Revista de Enfermagem, v. 12, n.4, p. 664-71, dez. 2008.

AUGÉ, M. Pessoa. Lisboa: Enciclopédia Einaudi, 1992.

AURELIANO, W.A. Vênus revisitada: negociações sobre o corpo na experiência do câncer de mama. Barbarói, Santa Cruz do Sul, n. 27, jul./dez. 2007.

AURELIANO, W.A. “...E Deus criou a mulher: reconstruindo o corpo feminino na experiência do câncer de mama”. Estudos feministas, Florianópolis, v. 17, n.1, p.296, jan./abr. 2009.

AZEVEDO, R.F.; LOPES, R.L.M. Merleau-Ponty e a compreensão da vivência de mulheres mastectomizadas em uso de prótese. Revista de enfermagem da UERJ, Rio de Janeiro, v.13, n.2, p.188-93, mai./ago. 2005.

AZEVEDO, R.F.; LOPES, R.L.M. Vivência do diagnóstico de câncer de mama e de mastectomia radical: percepção do corpo feminino a partir da fenomenologia. Online Brazilian Journal of Nursing, v.5, n.1, 2006.

BACKES, D.S., KOERICH, M.S., ERDMANN, A.L. Humanizando o cuidado pela valorização do ser humano: re-significação de valores e princípios pelos profissionais da saúde. Revista Latino Americana de Enfermagem, v.15, n.1, p.34-41, jan./fev. 2007. 
BARDIN, L. Análise de Conteúdo. Lisboa: Edições 70, 1979.

BARROS, A.J.; LEHFELD, N.A.S. Pesquisa Científica. 3ª ed., São Paulo: Markson Books, 1986.

BERTOLO, B.L.; PAULI, L.T.S. O papel da enfermagem como cuidadora nas questões das fragilidades da mulher pósmastectomia. Boletim da Saúde, Porto Alegre, v.22, n.1, jan./jun. 2008

BRAGANHOLO, L.P. de. A não realização de cirurgia reconstrutiva de mama: fatores associados, qualidade de vida e auto-estima. 2007. 134f. Dissertação (Mestrado) - Escola de Enfermagem de Ribeirão Preto, Universidade de São Paulo, Ribeirão Preto, 2007.

BRASIL. Ministério da Saúde. Instituto Nacional do Câncer. Rio de Janeiro, 2009.

Disponível em: <http://www.inca.gov.br/releases/press_release_view.asp?ID=2060> Acesso em: 14 jul. 2009.

BRASIL. Ministério da Saúde. Secretaria de Atenção à Saúde. Instituto Nacional do Câncer. Coordenação de Prevenção e Vigilância de Câncer. Estimativas 2010: Incidência de Câncer no Brasil. Rio de Janeiro, INCA, 2009. Disponível em: <

http://www.inca.gov.br/estimativa/2010/index.asp?link=conteudo_view.asp\&ID=5 >. Acesso em: 22 set. 2010.

BRASIL. Ministério da Saúde. Resolução nº 196/96 sobre pesquisa envolvendo seres humanos, 2009. Disponível em:<http://www.ufrgs.br/bioetica/res19696.htm>. Acesso em: 10 set. 2009.

BRASIL. Ministério da Saúde. DATASUS. Informações de saúde [Internet]. Brasília, 2009. Disponível em: <http://tabnet.datasus.gov.br/cgi/deftohtm.exe?sia/cnv/pauf.def $>$. Acesso em 05 abr. 2011.

BRASIL. Ministério da Saúde. Controle do câncer de mama: documento de consenso. Brasília: Ministério da Saúde, 2004. Disponível em:

<http://www.inca.gov.br/publicacoes/Consensointegra.pdf>. Acesso em: 20 jul. 2009.

BRASIL. Ministério da Saúde. Sistema Único de Saúde. Lei no 9.797, de 6 de maio de 1999. Dispõe sobre a Cirurgia Plástica Reparadora da mama pela rede do SUS.

Disponívelem:<http://www6.senado.gov.br/legislacao/ListaPublicacoes.action?id=226439>A cesso em: 31 ago. 2009.

CARVALHO, F.R.; CORREIA, C.M. Reconstrução mamária pós-mastectomia: dez anos de experiência no Hospital de Santarém. Acta Médica Portuguesa, Santarém, v.11, p.153-61, 1998. 
CHAGAS, C.R.; TONELLOTTO, F.; CARNEIRO, S.M. et al. Mastectomia com preservação de pele. Prática Hospitalar, ano X, n.56, mar./abr. 2008.

CHEN, J.Y.; MALIN, J.; GANZ,C.K. et al. Variation in Physician-patient Discussion of Breast Reconstruction. Journal of General Internal Medicine, v. 24, n. 1, p. 99-104, 2008.

CHIZZOTTI, A. A pesquisa qualitativa em ciências humanas e sociais: evolução e desafios. Revista Portuguesa de Educação, v.16, n.2, p. 221-36, 2003.

CORBELLINI, V.L. Câncer de mama: encontro solitário com o temor do desconhecido. Revista Gaúcha de Enfermagem, Porto Alegre, v.22, n.1, p.42-68, jan. 2001.

CYRILLO, P.I. Aspectos psicológicos. In: Reabilitação física no câncer de mama. São Paulo: Roca, 2000. Cap. 11.

DECAT, S.A. Níveis de satisfação em pacientes submetidas à reconstrução mamária imediata ou tardia. 2006. 71f. Trabalho de Conclusão de Curso de Especialização em Psicologia da Saúde e Hospitalar - Instituto de Ensino e Pesquisa da Associação de Combate ao Câncer em Goiás. Goiânia, Goiás, 2006.

DJOHAN, R.; GAGE, E.; BERNARD, S. Breast reconstruction options following mastectomy. Cleveland Clinic Journal of Medicine, v.75, Supl.1, Mar. 2008.

DONCATTO, L.F.; ASCOLI, T.A.C.; DIAS, E.S. Tratamento cirúrgico e reconstrutivo do câncer de mama bilateral: relato de caso e revisão bibliográfica. Arquivos Catarinenses de Medicina, v.36, Supl.1, 2007.

DUARTE, T.P.; ANDRADE, A.N. de. Enfrentando a mastectomia: análise dos relatos de mulheres mastectomizadas sobre questões ligadas à sexualidade. Estudos de Psicologia, Natal, v.8, n.1, jan./abr.2003.

FEIJÓ, A.M.; SCHWARTZ, E.; JARDIM, V.M.R. da. O papel da família sob a ótica da mulher acometida por câncer de mama. Ciência Cuidado e Saúde, v.8, supl., p.79-84, 2009.

FERNANDES, A.F.C., MAMEDE, M.V. Câncer de mama: mulheres que sobreviveram. Fortaleza: Ed. da UFC, 2003.

FREITAS JUNIOR, R.; RIBEIRO, L.F.J.; TAIA, L. et al. Linfedema em pacientes submetidas à mastectomia radical modificada. Revista Brasileira de Ginecologia e Obstetrícia, v. 23, n. 4, p. 205-08, 2001. 
GAHM, J.; JURELL, G.R.; WICKMAN, M. Sensitivity after bilateral prophylactic mastectomy and immediate reconstruction. Scandinavian Journal of Plastic and Reconstructive Surgery and Hand Surgery, v. 41, n.4, p. 178-83, 2007.

GASPARELO, C.; SALES, C.A.; MARCON, S.S. Percepções de mulheres sobre a repercussão da mastectomia radical em sua vida pessoal e conjugal. Ciencia Cuidado e Saúde, v.9, n.3, p.535-42, jul./set. 2010.

GOLDENBERG, M. Gênero e corpo na cultura brasileira. Psicologia Clínica. Rio de Janeiro, v. 17, n. 2, p. 65-80, 2005.

GOLDENBERG, M. Nu \& vestido. Rio de Janeiro: Record, 2002.

GOMES, R.; SKABA, M.M.V.F.; VIEIRA, R.J.S. Reinventando a vida: proposta para uma abordagem sócio-antropológica do câncer de mama feminino. Cadernos de Saúde Pública, Rio de Janeiro, v.18, n.1, jan./fev. 2002.

GOMES J.C.N. Sensibilidade tátil do retalho miocutâneo do reto abdominal em mulheres submetidas à reconstrução mamária imediata após mastectomia por câncer de mama. 2004. 83 f. Tese (Doutorado) - Faculdade de Ciências Médicas, Universidade Estadual de Campinas, São Paulo, 2004.

GREGÓRIO, T.C.R.; SBALCHIERO, J.C.; LEAL, P.R.A. Exame histopatológico das cicatrizes de mastectomia nas reconstruções tardias de mama: existe relevância oncológica? Revista Brasileira de Cancerologia, v.53, n.4, p. 421-24, 2007.

GUIMARÃES, G.S.; DAHER, J.C.; CAMAROTA, M.C. Reconstrução mamária com expansor permanente: uma outra alternativa. Revista Brasileira de Cirurgia Plástica, v.23, n.2, p.75-78, 2008.

HEIJER, M. D.; SEYNAEVE, C.; TIMMAN, R. et al. Body image and psychological distress after prophylactic mastectomy and breast reconstruction in genetically predisposed women: A prospective long-term follow-up study. European Journal of Cancer. 2011. doi:10.1016/j.ejca.2011.10.020

HUGUET, P.R.; MORAIS, S.S.; OSIS, M.J.D, et al. Qualidade de vida e sexualidade de mulheres tratadas de câncer de mama. Revista Brasileira de Ginecologia e Obstetrícia, Rio de Janeiro, v.31, n.2, fev. 2009.

INOCENTI, A.; RODRIGUES, I.G.; MIASSO, A.I. Vivências e sentimentos do cuidador familiar do paciente oncológico em cuidados paliativos. Revista Eletrônica de Enfermagem, v.11, n.4, p. 858-65, 2009. 
JESUS, L.L.C.; LOPES, R.L.M. Considerando o câncer de mama e a quimioterapia na vida da mulher. Revista de Enfermagem da UERJ, v.11, p.208-11, 2003.

LAVILLE, C.; DIONNE, J. A construção do saber: manual de metodologia de pesquisa em ciências humanas. Porto Alegre: Editora UFMG/Artmed, 1999.

LOMBARDI, P.J.A.; SILVA, H.M.S.; AHOUAGI, E. et al. Mapeamento pré-operatório das artérias perfurantes do músculo reto-abdominal com color-doppler em casos de reconstrução de mama: estudo de 30 casos. Revista Brasileira de Mastologia, v.12, n.3, 2002.

LOZANO, J. A.; ROLDÁN, P.; ESCUDERO, F. J. Reconstrucción mamaria con el colgajo musculocutáneo recto abdominal transverso (TRAM). Anales del Sistema Sanitario de Navarra, Pamplona, v.28, supl.2, 2005.

MAKLUF, A. S. D.; DIAS, R. C.; BARRA, A. A. Avaliação da qualidade de vida em mulheres com câncer da mama. Revista Brasileira de Cancerologia, v.52, n.1, p.49-58, 2006.

MALUF, M.F.M.; MORI, L.J., BARROS, A.C.S.D. O impacto psicológico do câncer de mama. Revista Brasileira de Cancerologia, Rio de Janeiro, v.51, n.2, p.149-54, abr. 2005.

MAUSS, M. As técnicas corporais. Sociologia e antropologia. São Paulo: EPU/EDUSP, 1974.

MINAYO, M.C.S. O desafio do conhecimento: pesquisa qualitativa em saúde. $9^{\text {a }}$ Ed. São Paulo: Hucitec, 2006. 406 p.

MOLINA, L.; DALBEN, I.; DE LUCA, L.A. Análise das oportunidades de diagnóstico precoce para as neoplasias malignas de mama. Revista da Associação Médica Brasileira, São Paulo, v.49, n.2, abr./jun. 2003.

MORROW, M.; MUJAHID, M.; LANTZ, P.M. et al. Correlates of breast reconstruction: Results from a population-based study. CANCER, v.104, n.11, p. 2340-46, 2005.

PAREDES, H.F; ALIAGA, N.A.; TREBILCOCK, J.J.G. et al. Reconstrucción mamaria: análisis crítico, indicaciones y resultados en CLC. Revista Médica de Clínica Las Condes, v.17, n.4, p. 237-43, 2006.

PETER, G.; CORDEIRO, M.D. Breast Reconstruction after Surgery for Breast Cancer. The New England Jornal of Medicine, v.359, n.15, p.1590-601, oct. 2008. 
PINHEIRO, C.P.O.; SILVA, R.M. da.; MAMEDE, M.V. Participação em grupo de apoio: experiência de mulheres com câncer de mama. Revista Latino-Americana de Enfermagem, Ribeirão Preto, v.16, n.4, Aug. 2008.

POLIT, D.E.; HUNGLER, B.P. Fundamentos de Pesquisa em Enfermagem. Tradução Regina Machado Garaz. $3^{\text {a }}$ ed., Porto Alegre: Artes Médicas, 1995.

REABY, L.L. Reasons why women who have mastectomy decide to have or not to have brast reconstruction. Plastic and Reconstructive Surgery, v.101, n.7, p.1810-18, jun. 1998.

REZENDE, M. C. R.; KOCH, H. A.; FIGUEIREDO, J. A. Causas do retardo na confirmação diagnóstica de lesões mamárias em mulheres atendidas em um centro de referência do Sistema Único de Saúde no Rio de Janeiro. Revista Brasileira de Ginecologia e Obstetrícia, v. 31, n. 2, p.75-81, 2009.

ROLDÁN, P.; LOZANO, J.; OROZ, J. Tratamiento de la mama contralateral en la reconstrucción mamaria. Reconstrucción de areola y pezón. Anales del Sistema Sanitario de Navarra, Pamplona , v.28, supl. 2, 2005.

ROSSI, L.; SANTOS, M.A. Repercussões psicológicas do adoecimento e tratamento em mulheres acometidas pelo câncer de mama. Psicologia Ciência e Profissão, v.23, n.4, p.3241, 2003.

SÁNCHEZ, E. C.; CAMACHO, A. R.; FERRER, A. D. et al. Satisfacción en pacientes con reconstrucción mamaria con colgajo D. I. E. P. / Patient's satisfaction after diep flap reconstruction. Cirurgía plástica ibero-latinoamericana, Madrid, v.32, n.3, p.169-78, jul./sep.2006.

SANTOS, M.J.F. A microcirurgia em reconstrução mamária - o retalho livre miocutâneo do recto anterior do abdômen. Acta Médica Portuguesa, Coimbra, v.11, p.253-57, 1998.

SILVA, G.; SANTOS, M.A. "Será que não vai acabar nunca?": perscrutando o universo do pós-tratamento do câncer de mama. Texto Contexto Enfermagem, Florianópolis, v.17, n.3, jul./set. 2008.

SILVA, L.C. da. câncer de mama e sofrimento psicológico: aspectos relacionados ao feminino. Psicologia em Estudo, Maringá, v. 13, n. 2, p. 231-37, abr./jun. 2008.

SOUZA, A.M.F. Informações, sentimentos e sentidos relacionados à reconstrução mamária. 2007. 105f. Dissertação (Mestrado) - Instituto Fernandes Figueira, Fundação Oswaldo Cruz, Rio de Janeiro, 2007. 
SPENCE, J.O. Cultural Sniping: The Art of Transgression. Routledge: London and New York, 1995.

TEIXEIRA, I. O resgate da auto-estima: o desafio de superar as repercussões do tratamento cirúrgico do câncer de mama. Revista Brasileira de Sexualidade Humana, v.19, n.1, jan./jun. 2008.

VIANNA, A.M.S.A. Avaliação psicológica de pacientes em reconstrução de mama: um estudo piloto. Estudos de Psicologia, Campinas, v.21, n.3,set./dez. 2004.

VIEIRA, C.P.; LOPES, M.H.B.M.; SHIMO, A.K.K. Sentimentos e experiências na vida das mulheres com câncer de mama. Revista da Escola de Enfermagem da USP, v.41, n.2, p. 31116, 2007.

WORLD HEALTH ORGANIZATION. National cancer control programmes: policies and managerial guidelines. 2 ed. Geneva: WHO; 2002.

YALOM, M. História do seio. 1 ed. , Lisboa: Editora Teorema, 1997. 
$\mathcal{A P} \hat{\mathcal{E}} \mathcal{N D I C E S}$ 


\section{APÊNDICE A}

\section{TERMO DE CONSENTIMENTO LIVRE E ESCLARECIDO}

Você está sendo convidada a participar da pesquisa intitulada "Significado da reconstrução mamária para mulheres mastectomizadas" que tem como objetivo compreender o que significa a reconstrução da mama para as mulheres que fizeram essas cirurgias (de retirada e de reconstrução da mama). Acreditamos que os resultados deste estudo poderão melhorar o seu atendimento e o das mulheres que frequentam o REMA. Para participar você deverá responder a um formulário com dados pessoais, como iniciais do nome, data de nascimento, escolaridade, ocupação, estado civil e às questões relativas ao tratamento do câncer de mama, incluindo as cirurgias de retirada e de reconstrução. Deverá ainda responder à questão: “ Conte-me o que significa para você ter sua mama reconstruída.” Nossa conversa será gravada e durará em torno de 30 minutos, em sua casa, no dia e no horário que você achar melhor. As fitas contendo as gravações ficarão guardadas sob nossa responsabilidade durante cinco anos e após esse período serão inutilizadas. Os resultados deste estudo serão divulgados apenas em artigos e eventos científicos. Sua identidade será mantida em segredo, e os dados que julgar secretos não serão revelados. Você poderá recusar o convite ou deixar de participar da pesquisa no momento que desejar. Para participar você não receberá dinheiro, nem terá outros ganhos materiais e também nenhuma despesa financeira ou prejuízo ao seu atendimento REMA. Caso apresente algum desconforto emocional durante as entrevistas, estarei pronta para confortá-la ou encaminhá-la para atendimento psicológico, caso seja necessário. Você e as pesquisadoras assinarão e ficarão com uma via assinada deste documento.

$\mathrm{Eu}$, concordo em participar da pesquisa realizada pela aluna Aline Inocenti, sob orientação da Profa. Dra. Marislei Sanches Panobianco. Endereço e telefone para contato com as pesquisadoras: Av. Bandeirantes, 3900 (Escola de Enfermagem de Ribeirão Preto/USP) - 3602-3480 - (16) 8157-0146.

\section{Assinatura}

Pesquisadoras:

Marislei Sanches Panobianco

Aline Inocenti 


\section{APÊNDICE B}

\section{INSTRUMENTO: ENTREVISTA COM A USUÁRIA}

\section{PARTE A - Caracterização das participantes do estudo}

1. Identificação (iniciais):

2. Data Nasc.:

3. Estado Civil
( ) Solteira
( ) Separada/divorciada
( ) Casada
( ) Amasiada/união consensual
( ) Viúva
( ) Outros

4. Ocupação

( ) Trabalhadora autônoma

( ) Aposentada

( ) Do Lar

( ) Desempregada

( ) Outros

( ) Trabalhadora com vínculo empregatício

5. Escolaridade
( ) Analfabeta
( ) Superior Completo
( ) Fundamental Completo
( ) Superior Incompleto
( ) Fundamental Incompleto
( ) Pós-Graduação
( ) Ensino Médio Completo
( ) Não Sabe
( ) Ensino Médio Incompleto

6. Tempo de diagnóstico do câncer de mama anos

7. Tempo de realização da mastectomia anos

8. Tempo de realização da cirurgia reconstrutora anos

9. Tipo de cirurgia reconstrutora 
Imediata ( ) Tardia ( )

10. Reconstrução pelo SUS? ( ) Sim ( ) Não

11. Finalização da cirurgia reconstrutora:

Sim ( ) N N N N N

PARTE B - Questão disparadora:

““Conte-me como foi para você realizar a reconstrução mamária” 
$\mathcal{A N E X O}$ 


\section{PARECER DO COMITÊ DE ÉTICA EM PESQUISA}

\section{COMITÉ DE ĖTICA EM PESQUISA DA EERP/USP}

Of.CLP-EERP/USP - 0174/2010

Ribeiraro Preto. 18 de agos to de 2010.

Prezada Senhora,

Comunicamos que a projeto de pesquisa, abaixo especificado, fọi analisado e mnsiderado APROVADO pelo Comitè dọ Étioa em Pesquisa da Escala de Enfermagem de Ribeirāo Preto a Universidade de Sa Paulo, em sua $130^{a}$ Reuniäo Ordinária, rea.izada em 18 de agusto de 2010.

Protocolo: $\quad n^{5} 1168 i 2010$

Projeto: $\quad$ SIGNIFICADO TA RECONSTRUÇĀO MAMARIA PARA MULHERES MAS゙I EETOMIZADAS.

Pesquisadores: Marislei Sanches Panobianco

Aline Inocenti

Em atendimento à Resoluçăo 196/96, deverá ser ençaminhado a CEP o relatório final da pesquisa e a publicaça de seus resultados, para acompanhamento, bers como comunicada quakquer intercorrencia ou a sua interrupçāa.

$$
\begin{aligned}
& \text { Atenciosamente, } \\
& \text { Prof Drace Lucila Castanheira Nascimento } \\
& \text { Codcenadora do CEP-EERPJSP }
\end{aligned}
$$

Itma. Sra.

Prof. Dr. Martslei Sanches Panobianco

Departamento de Enfermagem Materno-Infantil e Saùde Pública

Escole de Enfermagem de Ribeirăo Pretr - USP 